\title{
燕山-太行山北段中生代收缩变形与华北克拉通 破坏
}

\author{
张长厚"，李程明，邓洪菱，刘阳，刘否，魏波，李寒滨，刘孜 \\ 中国地质大学地质过程与矿产资源国家重点实验室, 北京 100083 \\ *E-mail: changhou@cugb.edu.cn
}

收稿日期: 2010-08-05; 接受日期: 2011-01-30

国家自然科学基金重大研究计划(批准号: 90814007)和国家自然科学基金面上项目(批准号: 40672150,40272086)资助

\begin{abstract}
摘要燕山-太行山中生代收缩构造变形主要表现为基底卷入的逆冲构造、基底为核的大型 纵弯褔皱构造, 以及韧性逆冲推覆构造. 构造形迹展布方向主要有近 WE, NWW和 NE-NNE向. 在总体构造线呈 NNE 向展布的太行山构造带和辽西燕山东段, 均发现有近 WE 向和 NWW 向 收缩构造变形. 收缩变形发生在二叠纪晚期、三叠纪、侏罗纪及早白严世. 它们的发生已经使 克拉通遭受破坏. 燕山中部近 NS 向构造剖面复原表明, 在 $135 \mathrm{Ma}$ 之前的构造变形缩短率约为 38\%. 华北东部晚古生代和早中生代岩相古地理研究显示, 收缩变形前的地壳厚度约为 $35 \mathrm{~km}$. 如果将上述地质历史时期韧性剪切收缩变形反映的变形深度 (20 25 km) 作为卷入收缩变形的 地壳厚度, 并假定水平缩短变形量由垂向地壳加厚所调节, 则在南北向缩短变形之后地壳厚度 可达 47 50 km, 已经接近拆沉构造模型下地壳榴辉岩化所需的地壳厚度. 同时, 加厚地壳均衡 抬升产生的重力势能差, 与地壳加厚期间持续不断的岩浆活动导致的岩石圈强度弱化, 为在区 域构造应力状态不发生改变的情形下产生中浅部地壳的伸展垮塌创造了充分条件. 因此, 燕山一 太行山中生代收缩构造变形, 一方面直接导致了克拉通岩石圈浅层稳定状况的破坏, 另一方面 为在深部可能发生的拆沉作用和在浅部产生强烈伸展变形创造了有利条件. 拆沉作用和伸展 变形可能同是早期收缩变形导致地壳强烈加厚的结果. 伸展变形既可以与拆沉作用相伴发生, 也可以单独出现, 不宜将浅层伸展变形作为深部拆沉作用曾经发生的直接证据.
\end{abstract}

关键词

华北克拉通

燕山

太行山

收缩变形

重力垮塌
华北克拉通的破坏包含了岩石圈厚度的巨量 $(>120 \mathrm{~km})$ 减薄、地幔物质组成及热状态的剧烈变化 以及强烈的构造变形 ${ }^{[1 ~ 8]}$. 主要基于岩浆活动特征研 究, 在克拉通岩石圈减薄的时空范围、减薄的过程与 机制等方面取得了一系列重要进展和成果. 关于克 拉通岩石圈减薄的峰期时间(130 110 Ma)也取得了
比较一致的认识 ${ }^{[9 \sim 13]}$. 但是, 关于岩石圈减薄的起始 时间, 则有古生代末 ${ }^{[13]}$ 、晚石炭-晚三叠世 ${ }^{[14]}$ 、晚三 叠世 ${ }^{[11]}(225 \sim 205 \mathrm{Ma})$ 、早侏罗世 ${ }^{[9,10,12]}(190 \sim 180 \mathrm{Ma})$ 、 晚侏罗世 ${ }^{[1,15]}(160 \mathrm{Ma}) 、$ 晚侏罗-早白严世初(160 140 $\mathrm{Ma})^{[5]}$ 和早白严世末 $(100 \mathrm{Ma})^{[16]}$ 等不同认识. 关于岩 石圈减薄的机制, 主要有岩石圈拆沉模型、热-机械与

英文引用格式: Zhang C H, Li C M, Deng H L, et al. Mesozoic contraction deformation in the Yanshan and northern Taihang mountains and its implications to the destruction of the North China Craton. Sci China Earth Sci, 2011, 54: 798-822, doi: 10.1007/s11430-011-4180-7 
化学侵蚀模型和地幔交代与置换模型等主要认识.

主张拆沉作用模型的众多学者, 尽管在拆沉的 时间、范围、层次和方式等方面存在不同认识, 但都 认为拆沉作用发生前曾经发生过显著的地壳加厚,

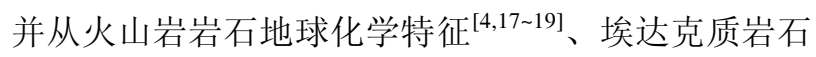
的特征与分布 ${ }^{[19-26]}$ 和火山岩深源包体特征分析的角 度 ${ }^{[27]}$ 分别论证了中生代时期加厚地壳的存在. 但是 这些研究并未揭示和证明地壳加厚的具体方式和加 厚幅度.

众所周知，在华北克拉通东部中生代时期曾经 发生广泛而强烈的收缩变形, 对其中一些具体构造 变形的研究已近百年. 但是, 这些在时间上发生在稳 定的克拉通状态(约 457 460 Ma) 和遭到破坏的克拉 通状态(130 110 Ma)期间, 空间上分布于克拉通破坏 范围之内的岩石圈浅层收缩构造变形, 在克拉通地 壳加厚和破坏过程中发挥了怎样的作用, 目前为止 并不清楚. 为此, 本文拟通过对这些收缩变形的构造 样式、时-空分布和典型区域收缩变形造成的地壳缩 短与加厚效应的研究, 探索它们对浅层伸展变形及 深部拆沉作用的可能影响和对克拉通破坏方式及破 坏过程的意义. 为了陈述方便, 文中将介于鄂尔多斯 盆地东缘以东到渤海湾-华北盆地西界以西的区域笼 统地称作太行山地区或太行山构造带.

\section{1 收缩变形构造样式}

燕山和太行山地区中生代构造变形, 是在具有 强硬的结晶基底及稳定的沉积盖层组成的克拉通浅 层地壳结构的基础上发生的, 与在被动大陆边缘沉 积楔形体基础上发育的俯冲或碰撞造山带外缘前陆 褶皱逆冲带收缩变形存在着显著差异. 由于不存在被 动大陆边缘发育的早期海侵作用之初形成的蒸发岩沉 积, 因此, 虽然在盖层岩系和下伏基底变质结晶岩系 之间存在岩石力学性质的差异, 但这种界面也难以起 到蒸发岩系那样的滑脱层作用, 从而更多地表现为刚 性基底与上覆层状沉积盖层一起卷入收缩变形.

\section{1 基底卷入的大型逆冲推覆构造}

基底卷入的大型逆冲推覆构造是燕山和太行山 一带收缩变形的重要构造样式之一. 位于前人所谓 “燕辽沉降带” 北缘、长期被看作深大断裂的尚义-赤 城-丰宁-隆化-凌源-北票断裂(图 1), 是燕山北部最重
要、规模最大的基底变质岩系卷入逆冲构造变形的实 例 ${ }^{[28 ~ 32]}$. 沿着它, 原“内蒙地轴”区域的变质岩系逆冲 于燕山沉降带中元古代沉积岩系以及中生代陆相沉 积岩系之上. 与脆性断裂系统平面展布方向大致平 行的方向上, 发育强烈的韧性剪切变形, 总体上表现 为倾向北, 上盘向南的逆冲作用. 㓞性变形矿物组合 特征和糜棱岩形成 $P-T$ 环境研究结果 ${ }^{[33 \sim 35]}$ 显示, 韧性 逆冲变形形成于高角闪岩相条件下, 相当于 $20 \sim 25$ $\mathrm{km}$ 深度范围 ${ }^{[33]}$. 逆冲型㓞性剪切带同变形黑云母和 角闪石 ${ }^{40} \mathrm{Ar}{ }^{39} \mathrm{Ar}$ 测年结果表明, 深层次韧性变形曾 经先后发生在二叠纪晚期 $(263 \mathrm{Ma})^{[36]}$ 和中侏罗世 $(163 \mathrm{Ma})^{[35]}$. 而在逆冲构造前缘形成的类似于前陆盆 地的小型盆地沉积及其沉积相特征与变形作用 ${ }^{[37 \sim 41]}$ 表明, 至少在晚侏罗世土城子组沉积期间和之后它 还曾发生上盘向南的脆性逆冲变形.

冀西北下花园-北京延庆西北部和张家口市万全 县非菜沟-小蒜沟一带的逆冲构造, 表现为基底与盖 层岩系共同卷入变形的逆冲构造 ${ }^{[32]}$. 燕山中部兴隆 逆冲构造 ${ }^{[22-45}$ 和承德县西部鞍匠-孟家庄一带的逆冲 构造(AMF)(图 2 和 3(a))也表现为基底与盖层共同卷 入逆冲变形的构造样式.

燕山东段冀辽省界区域及辽西地区的逆冲构造, 除了上述凌源-北票断裂呈现为基底卷入式变形 ${ }^{[30]}$ 以 外, 迁西县喜峰口-宽城县峪耳崖-凌源县雱神庙逆冲 构造(XBT)(图 1 和 2)中段亦呈现为基底卷入式逆冲 构造. 河坎子-南公营子逆冲构造(HNT)(图 1)和建昌朝阳-北票逆冲系统(JCBT)(图 1)等, 尽管在逆冲构造 中部区域主要表现为逆冲变形发育在盖层内部的薄 皮构造特征 ${ }^{[32,46,47]}$, 但是, 在这些逆冲断层向西南部 延伸时也呈现为基底共同卷入变形的情形(图 3(b)). 锦州西部红螺岘和南票一带, 更清楚地表现出基底 与上覆长城系地层一起卷入逆冲构造变形的变形样 式(图 1) ${ }^{[30]}$.

太行山北部大同盆地西缘中生代逆冲构造 $(\mathrm{DET})^{[48 \sim 50]}$ (图 1 和 3(c)) 和忻州-定襄-五台东南部的系 舟山逆冲构造(XZT)(图 1) ${ }^{[51]}$, 亦都具有基底与盖层 一起卷入变形(图 3(d)) 的构造特征.

\section{2 基底为核的大型纵弯褶皱构造}

基底为核的大型纵弯褶皱构造是燕山和太行山 地区中生代收缩变形的另一种重要构造样式. 冀东 马兰峪背斜(MLYA)(图 1 和 2)过去被认为是印支期 


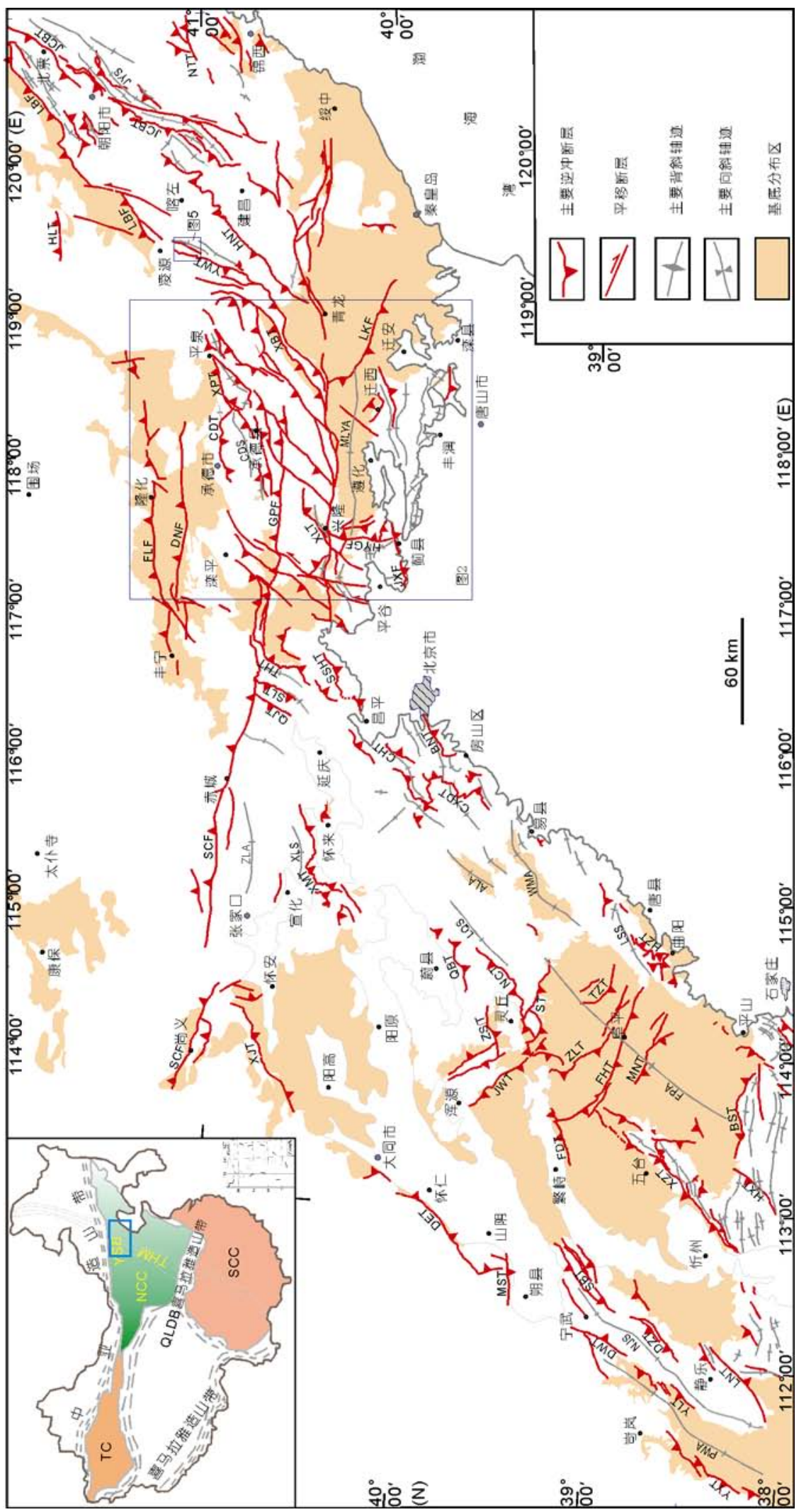

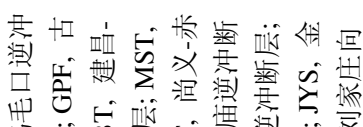

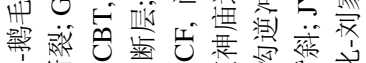

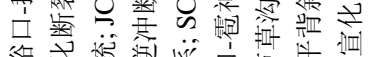

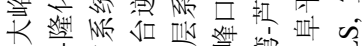

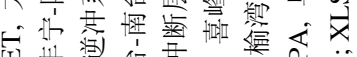

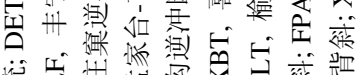

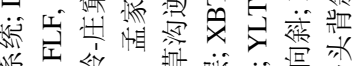

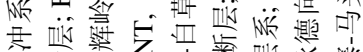

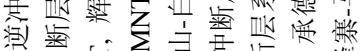

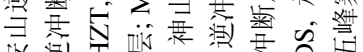

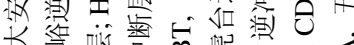

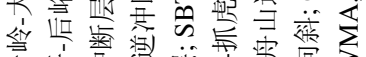



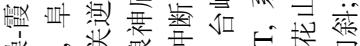

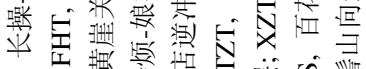

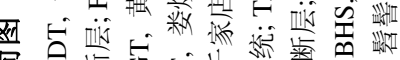

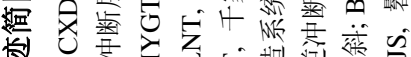

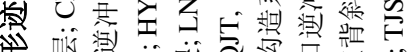

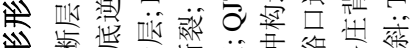

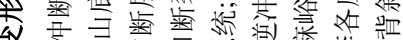

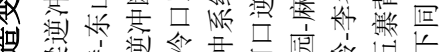

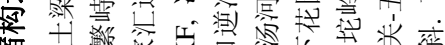

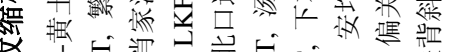

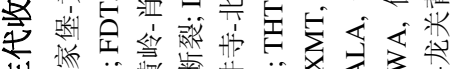

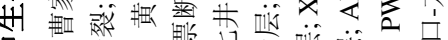

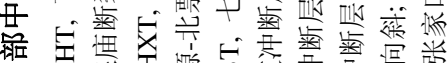

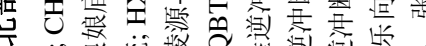

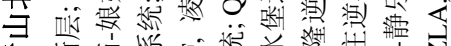

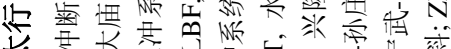

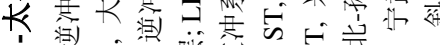

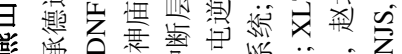

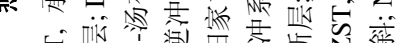

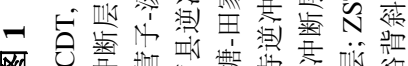

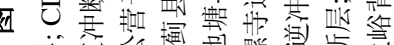

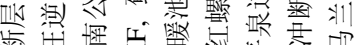

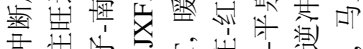

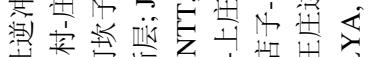

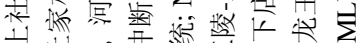

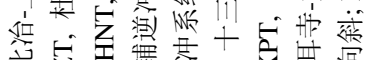

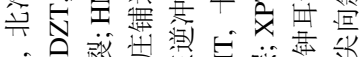

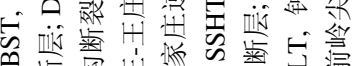

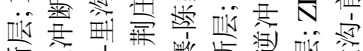

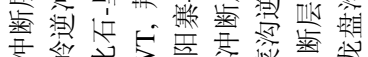

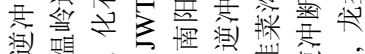

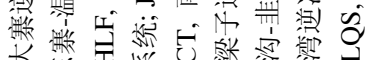

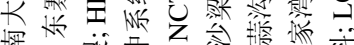

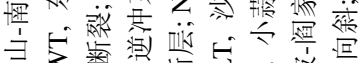

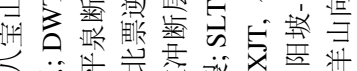

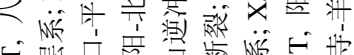

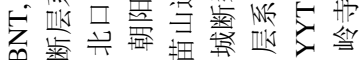




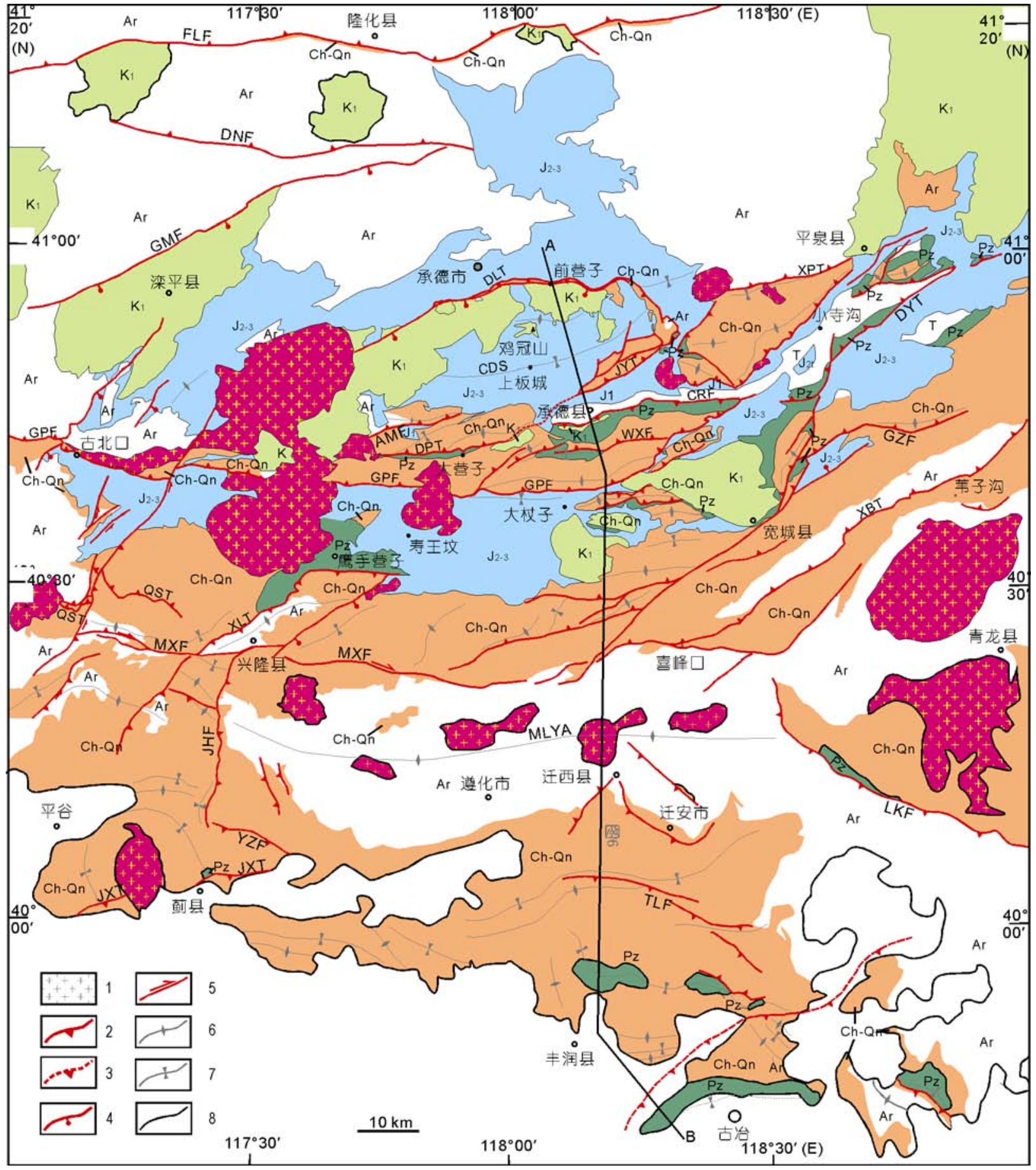

图 2 燕山中部构造图

1 , 中生代侵入岩; 2 , 主要逆冲断层; 3 , 隐伏及推测逆冲断层 $; 4$, 主要正断层; 5 , 走滑断层; 6 , 背斜轴迹; 7 , 向斜轴迹; 8 , 一般地质界线; MXF, 密云-喜峰口断裂; JXT, 薊县逆冲断层 

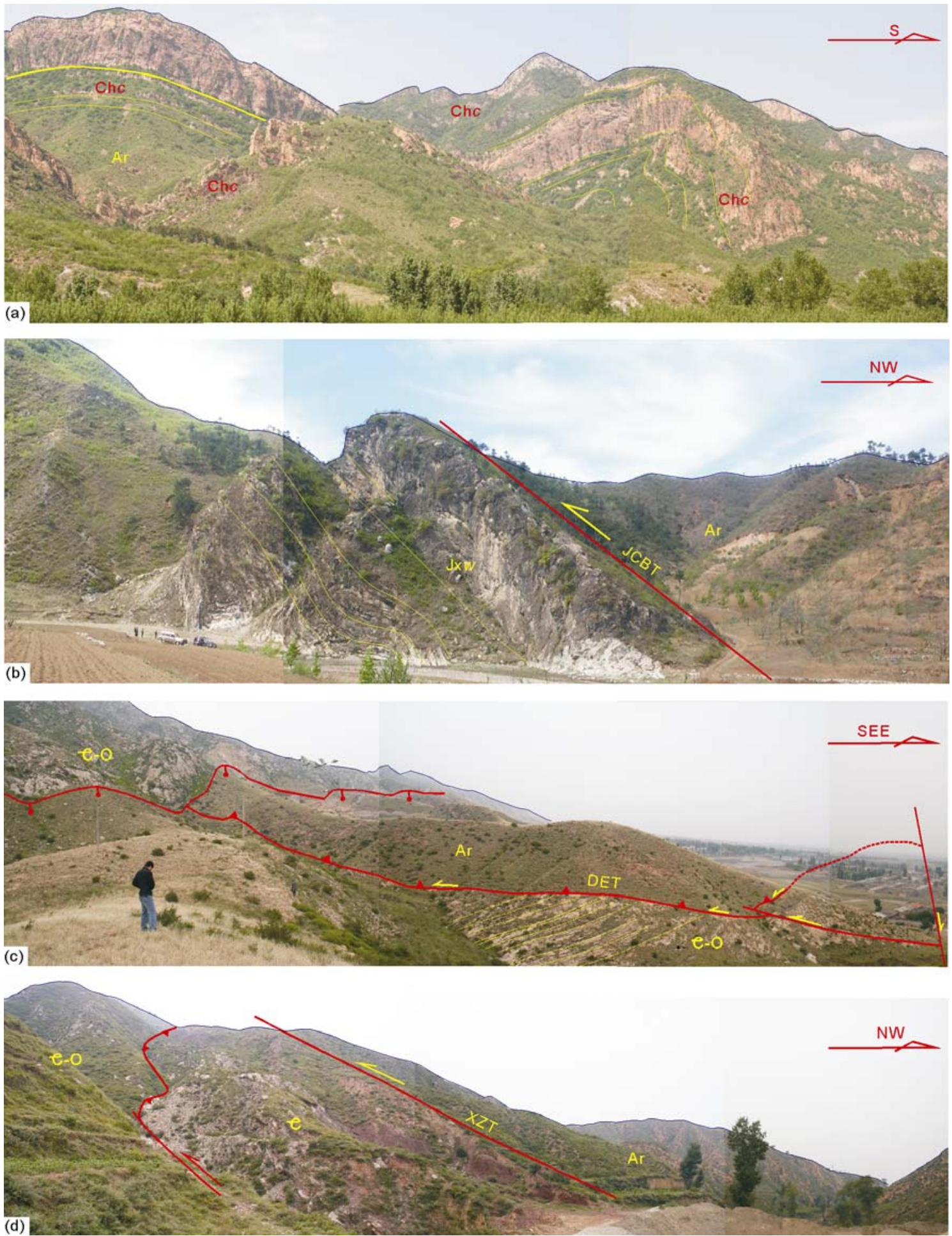

图 3 构造变形图片

(a) 承德县西部鞍厈-孟家庄逆冲构造上盘基底为核的褟坡构造; (b) 青龙县北部张家店太古界基底( $\mathrm{Ar}$ ) 逆冲于蓟县系雾迷山组(Jxw)之上; (c) 山西大同西部沿大峪口-鹅毛口逆冲断层(DET)太古界变质岩系(Ar)逆冲于寒武-奥陶系之上; (d) 山西忻州东南部太古界基底(Ar)沿系舟山逆 冲断层(XZT)逆冲于寒武-奥陶系之上, 断层下盘地层倒转. $\mathrm{Ch} c$, 长城组 
或燕山早期南北向收缩构造变形的产物, 但在 20 世 纪 90 年代后期以来被不少研究者认为是伸展变质核 杂岩构造 ${ }^{[52 \sim 58]}$, 并被作为中国东部中生代大陆伸展 构造变形的典型变形形式 ${ }^{[59,60]}$. 研究发现, 这些所谓 变质核杂岩并不具备典型变质核杂岩应有的基本构 造要素, 如大规模低角度拆离断层及上覆岩系中的 高角度断层系列和下伏岩系顶部的低角度韧性剪切 带等 ${ }^{\left[{ }^{[} 163\right]}$. 在马兰峪背斜北翼 ${ }^{[64]}$ (图 4(a))、南翼及西 部转折端一带开展的构造变形研究 ${ }^{[65]}$ 都表明它是近 南北向缩短变形期间形成的、基底与盖层共同卷入变 形的大型褶皱构造.

太行山北部阜平和赞皇隆起长期被认为是古老 的片麻岩穹隆. 20 世纪 90 年代中期以来, 牛树银 等 ${ }^{[66 ~ 69]}$ 提出了阜平隆起和赞皇隆起是中生代、新生代 形成的变质核杂岩的认识, 并指出区域褶皱构造是 横弯褶皱作用的产物。这种认识被一些学者引

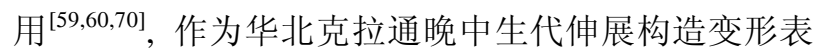
现之一. 但是, 最近的构造变形研究结果 ${ }^{[51,71 ~ 74]}$, 以 及部分热年代学研究结果 ${ }^{[75]}$ 并不支持上述变质核杂 岩构造模型. 我们在太行山北段东麓河北易县、满城 和唐县西北部一带的初步研究发现, 在盖层岩系当 中发育有一系列逆冲构造变形及相关褶皱构造, 区 域褶皱内部发育的次级褶皱和断裂构造也显示出典 型的纵弯褶皱变形特征, 在基底与盖层之间或者基 底内部尚未发现变质核杂岩构造的必要构造要 素——大规模拆离断层及低角度韧性剪切带等. 盖 层岩系与下伏深变质岩系之间为正常的角度不整合 接触. 而且, 在阜平隆起结晶变质岩系分布区域的南 缘, 发现基底变质岩系向南逆冲于上覆寒武-奥陶系 盖层沉积岩系之上(BST)(图 1 和 4(b)). 皁平隆起中部 神仙山南侧, 亦见有基底变质岩系和中元古界盖层 岩系向北逆冲于寒武系紫红色泥岩之上(ZLT)(图 1 和 4(c)), 因此, 阜平隆起表现出曾遭受近南北向缩短和 NW-SE 向缩短变形的叠加变形, 不是伸展变形导致 的大面积基底变质岩系剥露的产物.

上述特征表明, 燕山中部的马兰峪背斜、太行山 北段的赞皇隆起和皁平隆起, 是基底与盖层共同卷 入收缩变形产生的大型基底为核的纵弯褶皱, 或可 称作厚皮褶皱构造 ${ }^{[76]}$.

\section{3 大型倒转褶皱与韧性逆冲推覆构造}

除了在尚义-崇礼-赤城一带发现有反映深层收 缩变形的韧性剪切逆冲构造 ${ }^{[28,33,35,36]}$ 之外, 在京北燕
山中段也发现有形成时代更晚的大型倒转褶皱与韧 性逆冲推覆构造 ${ }^{[77]}$, 以北京密云四合堂大规模基底 卷入的褶皱推覆构造及四合堂韧性逆冲剪切带为代 表. 基底为核的褶皱逆冲构造倒转翼厚约 $15 \mathrm{~km}$, 韧 性逆冲剪切带厚逾 $6 \mathrm{~km}^{[77,78]}$. 它们的存在表明在侏 罗纪末-早白严世初曾经发生强烈的收缩变形与浅部 地壳加厚作用, 并可能导致了其前、后岩浆岩成分特 征的显著变化 ${ }^{[77]}$. 该韧性逆冲推覆构造与尚义-赤城 㓞性-脆性多相逆冲构造共同反映了晚古生代末以来 直到晚中生代, 燕山地区卷入收缩变形的较深层次 构造特征.

\section{2 收缩变形空间分布特征}

太行山北部和燕山地区的收缩构造, 在空间上 主要表现为 WE-NWW 向和 NE-NNE 向展布.

\section{1 近 WE 向和 NWW 向收缩变形}

近 WE 和 NWW 向展布的收缩构造见于太行山 北部和整个燕山构造带, 以燕山中部的近东西向构 造最具有代表性.

燕山构造带中部的收缩构造变形, 主要由一系 列近东西向展布的逆冲构造和大型褶皱构造组成(图 1 和 2). 主要逆冲构造自北而南依次为丰宁-隆化断 裂、大庙娘娘庙断裂和古北口-平泉断裂, 都表现为上 盘向南的逆冲或斜冲作用 ${ }^{[31]}$, 褶皱构造主要有北部 的承德向斜(CDS)和南部的马兰峪背斜(MLYA)(图 1 和 2). 位于古北口-平泉断裂和大庙-娘娘庙断裂之间 的承德向斜两翼的逆冲断层, 曾被认为是一个大型 襀皱变形的逆冲构造, 沿着它发生的水平位移超 过 $35 \mathrm{~km}^{[79]}$. 近年来, 这一模型遭到中生代沉积岩 相 ${ }^{[00,81]}$ 和中生代构造变形研究 ${ }^{[82 ~ 84]}$ 的质疑, 但并未 对该区域复杂构造面貌提出更加合理的解释. 本次 研究证实, 承德向斜北翼的大庙-六沟逆冲断层 (DLT) (图 2) 和南部的吉余庆-影北山逆冲断层 (JYT)(图 2)是形成时间基本一致(147 135 Ma)、自承 德向斜核部分别向向斜之外逆冲的背离向斜逆冲断 层(out-of-syncline thrust), 而不是一条大型低角度逆 冲断层褶皱变形的结果. 承德向斜东部转折端南侧 以及南翼西段的鞍匠-孟家庄逆冲构造(AMF)(图 2 和 4(d)) 及大营子-潘家店逆冲断层(DPT)(图 4(d)), 都表 现为基底变质岩系和上覆长城系盖层一起向南逆冲 

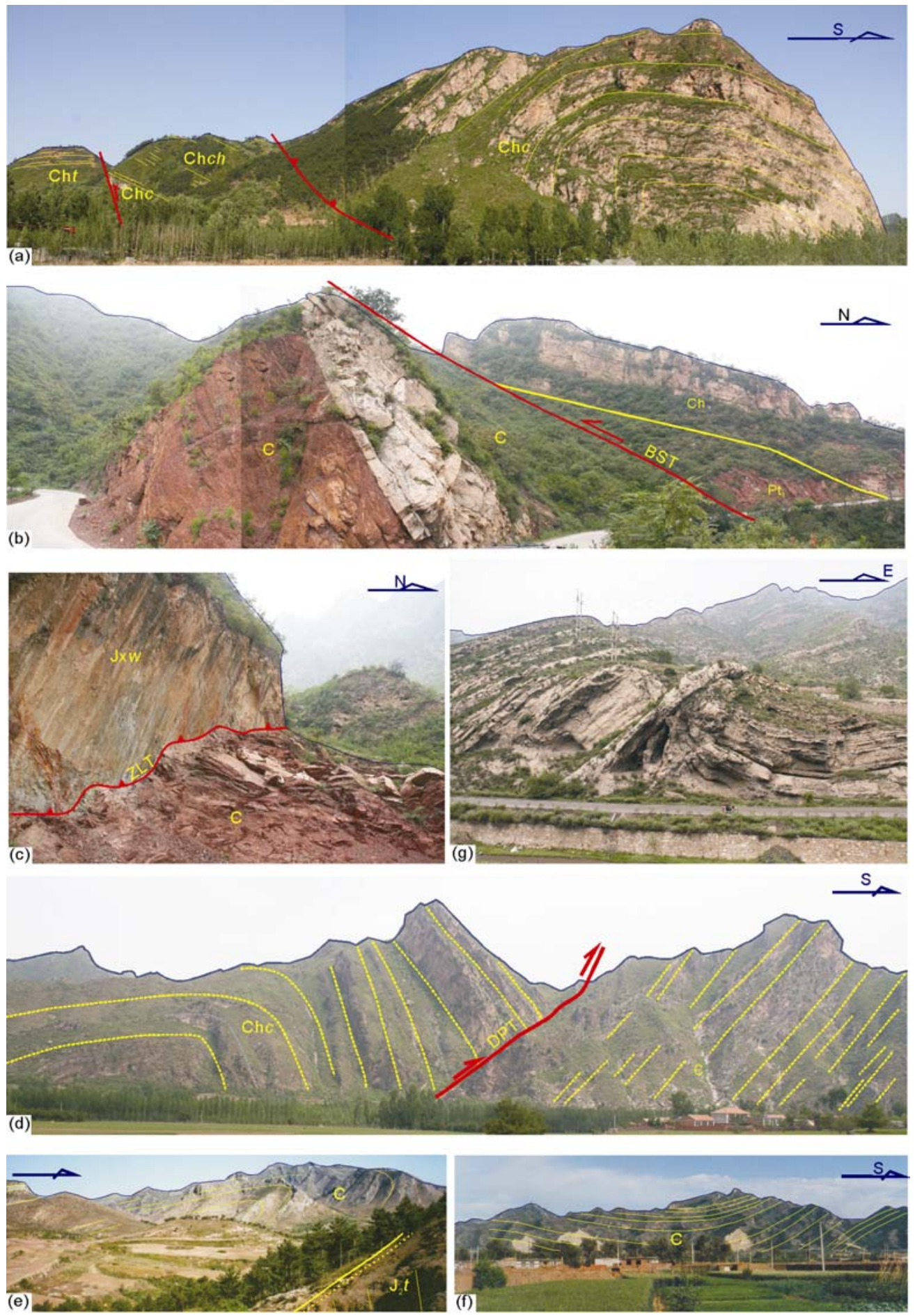

图 4 构造图片

(a) 河北遵化龙井关马兰峪背斜北翼的逆冲断层与相关褶皱; (b) 阜平背斜南端沿北冶-上社逆冲断层 $(\mathrm{BST})$ 早元古界 $\left(\mathrm{Pt}_{1}\right)$ 变质岩和上覆长城 系地层 $(\mathrm{Ch})$ 向南逆冲于寒武系之上, 寒武系地层发生倒转; (c) 阜平背斜中部神仙山南蓟县系雾迷山组(Jxw)沿钟耳寺-龙王庄逆冲断层(ZLT) 逆冲于寒武系紫红色泥岩之上; (d) 承德县西部沿大营子-潘家店逆冲断层(DPT)常州沟组(Chc)逆冲于寒武系之上; (e) 辽宁喀左窟窟山附近 近东西向倒转褶皱构造; (f) 朝阳市东南部风凰山寒武系地层中的近东西向褶皱; (g) 大同西部大峪口-鹅毛口逆冲断层下盘奥陶系地层中的 强烈褶坡变形. Ch $c$, 常州沟组; $\mathrm{Ch} c h$, 串岭沟组; $\mathrm{Ch} t$, 团山子组 
于古生界和晚侏罗世土城子组地层之上, 造成了较 大规模的水平缩短和垂向地壳加厚.

NNE 向太行山构造带中, 也发现有一系列重要 的近东西向和 NWW 向收缩构造变形. 在太行山中部 的石家庄-忻州-静乐南部一带, 一系列近东西向展布 的褶皱和逆冲构造分布在南北宽约 $32 \mathrm{~km}$ 、东西长约 $177 \mathrm{~km}$ 的带状区域内(图 1), 区域性不对称褶皱轴面 以向北倾居多. 逆冲构造中包括阜平背斜南端基底 变质岩系向南逆冲于古生界盖层之上的北冶-上社逆 冲断层(BST)(图 1 和 4(b)). 另外, 在皁平背斜核部也 发现有一系列 NWW 走向、上盘向北逆冲的收缩变形, 如阜平-后峪逆冲断层(FHT)、孟家台-南台逆冲断层 (MNT) 以及钟耳寺-龙王庄逆冲断层(ZLT)(图 1 和 4(c)). 在阜平背斜核部变质岩系大面积出露区域的 北部, 沿着荆庄-王庄铺逆冲断层 (JWT) 和水堡逆冲 断层(ST), 基底变质岩系和部分长城系地层向北逆冲 于蓟县系、古生界及土城子组地层之上(图 1).

此外, 在总体构造展布 NE-NNE 向的辽西地区 燕山东段, 也发现有被 NE-NNE 向逆冲构造及相关 褶皱变形包含的早期 NWW-WE 向逆冲断层和褶皱 构造. 在凌源南部瓦房店一带(图 5)、沟门子西北部, 喀左五十家子东南部(图 4(e))、南公营子镇西部和南 部、朝阳市东南部风凰山(图 4(f)) 及建昌-朝阳逆冲断 层上盘岩席、朝阳西北部边杖子西部、冀辽省界河北 青龙东北部张家店和辽西凌源河坎子等地, 都发现 有早于 NE-NNE 向逆冲构造和褶皱变形的早期褶皱 和逆冲构造. 由于这些近东西向和 NWW 向构造被随 后形成的 NE-NNE 向收缩构造和伸展构造等强烈改 造, 总体面貌已不再连续清晰.

\subsection{NE 向收缩变形}

\subsection{1 太行山构造带}

太行山北段以逆冲构造及区域性纵弯褶皱为代 表的收缩变形可以大致分为西部、中部和东部三个 带.

西带位于山西离石和大同到河北怀安西部一带, 自南向北依次为阳坡-阎家湾逆冲系 $(\mathrm{YYT})$ 、大同西部 的大峪口-我毛口逆冲系(DET)和小蒜沟-韭菜沟逆冲 构造(XJT)(图 1), 各段断层产状和相应的上盘逆冲方 向并不完全一致. 南部的阳坡-阎家湾逆冲构造, 倾 向 $\mathrm{NW}$, 上盘基底变质岩系向南东逆冲于寒武-奥陶
系盖层之上. 在偏关-五寨隆起东北部与宁武-静乐向 斜(NJS)相邻的区域，表现为自背斜隆起区域往东南 的向斜区域的逆冲——榆湾-芦草沟逆冲系统 (YLT)(图 1), 并导致宁武向斜西翼的倒转. 中段为分 布于大同盆地西侧的大峪口-鹅毛口逆冲构造, 后部 表现为基底卷入的逆冲构造(图 3(c)), 前部盖层岩系 当中也发育强烈的收缩变形(图 4(g)), 中间表现为沿 着石炭系非能干岩系楔入式逆冲并导致上覆岩层发 生断弯褶皱的构造样式(图 6(a)). 但在中段南部的吴 家窑附近，逆冲断层倾向 NW，上盘向南东逆冲，而 且逆冲断层具有沿着基底变质岩系各向异性面理向 上扩展延入盖层岩系的构造面貌(图 6(b)). 北段位于 张家口怀安西北部小蒜沟-韭菜沟一带, 基底与盖层 共同卷入变形并向 NW 逆冲 ${ }^{[32]}$.

宁武-静乐向斜(NJS)及其伴生的背离向斜逆冲 构造是西带收缩构造变形的一个重要组成部分, 也 是太行山北部发育和保存比较完整的中生代褶皱构 造. 它 NE 向展布, 长约 $160 \mathrm{~km}$, 宽约 $25 \mathrm{~km}$, 核部相 对开阔宽缓, 两翼较陡, 且在两翼发育自向斜核部向 翼部逆冲的背离向斜逆冲构造, 北西翼以东寨-温岭 逆冲构造(DWT)为代表(图 1 和 6(c)), 南东翼以杜家 村-庄旺逆冲系(DZT) 和神山-白草沟逆冲系统 (SBT) 为代表(图 1).

中带位于太行山隆起区中部，由三段组成. 南段 由前人所谓系舟山逆冲系统(XZT) ${ }^{[51]}$ (图 1)为主组成, 沿逆冲带基底变质岩系向南东逆冲于寒武-奥陶系之 上，导致这些盖层岩系的剧烈陡倾甚至倒转(图 3(d)), 并在局部区域仍保留有逆冲构造产生的飞来峰构 造 ${ }^{[51]}$. 上盘基底内部表现为典型的脆性变形(图 6(d)) 并发育有约 $20 \mathrm{~cm}$ 厚的绿泥石化角砾岩(图 6(e)). 中 段位于广灵南部, 基底变质岩系和上覆长城系高于 庄组及蓟县系雾迷山组一起, 沿南阳寨-陈家庄逆冲 系(NCT)向南东逆冲于寒武-奥陶系及上覆土城子组 之上(图 1). 北段即位于怀来-延庆新生代盆地西缘的 冀西北下花园-麻峪口逆冲构造(XMT)(图 1), 燕山地 区著名的鸡鸣山逆冲推覆构造属于该构造系统的中 部. 它与中段和南段的逆冲构造表现为上盘向南东 的逆冲不同, 主要表现为中元古界盖层岩系向 NW 逆冲于侏罗系髺䯽山组及土城子组之上 ${ }^{[32]}$, 上盘元 古界地层内部发育一系列次级逆冲断层(图 6(f), (g)). 在延庆西部，基底变质岩系沿该逆冲构造掩覆于长 城系和中生代地层之上 ${ }^{[32]}$. 


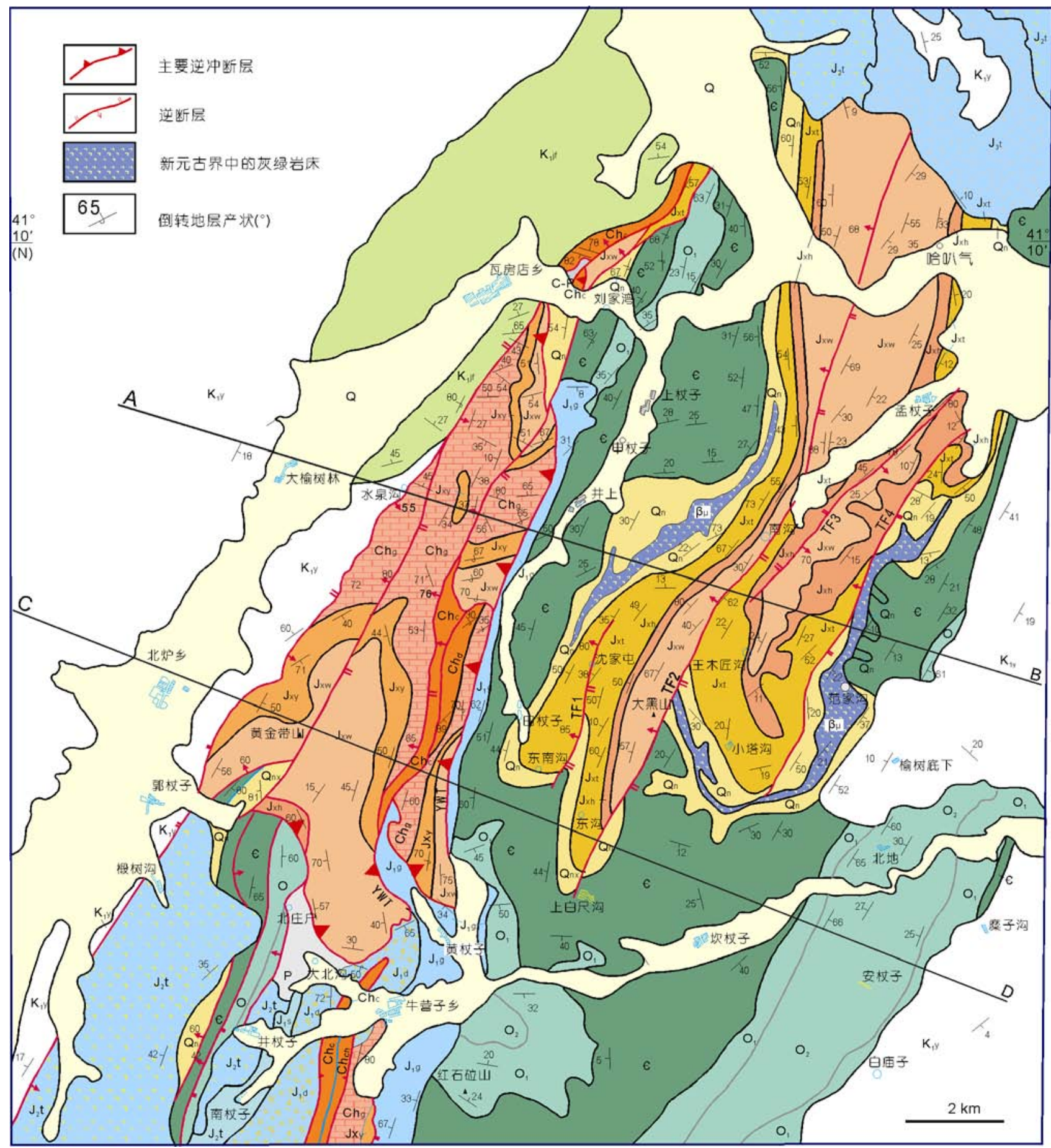

图 5 辽西凌源南部瓦房店一带地质构造图

$\mathrm{Q}$, 第四系; $\mathrm{K}_{1} j f$, 九佛堂组; $\mathrm{K}_{1} y$, 义县组; $\mathrm{J}_{2} t$, 髺䯽山组; $\mathrm{J}_{1} s$, 水泉沟组; $\mathrm{J}_{1} d$, 邓杖子组; $\mathrm{J}_{1} g$, 郭家店组; $\mathrm{P}$, 二叠系; C-P, 石炭-二叠系 (未分); $\mathrm{O}_{2}$, 中奥陶统; $\mathrm{O}_{1}$, 下奥陶统; $\mathrm{Qn}$, 青白口系; $\mathrm{Jx} t$, 铁岭组; $\mathrm{Jx} h$, 洪水庄组; $\mathrm{Jx} w$, 雾迷山组; $\mathrm{Jx} y$, 杨庄组; $\mathrm{Ch} g$, 高于庄组; Ch $d$, 大红峪组 

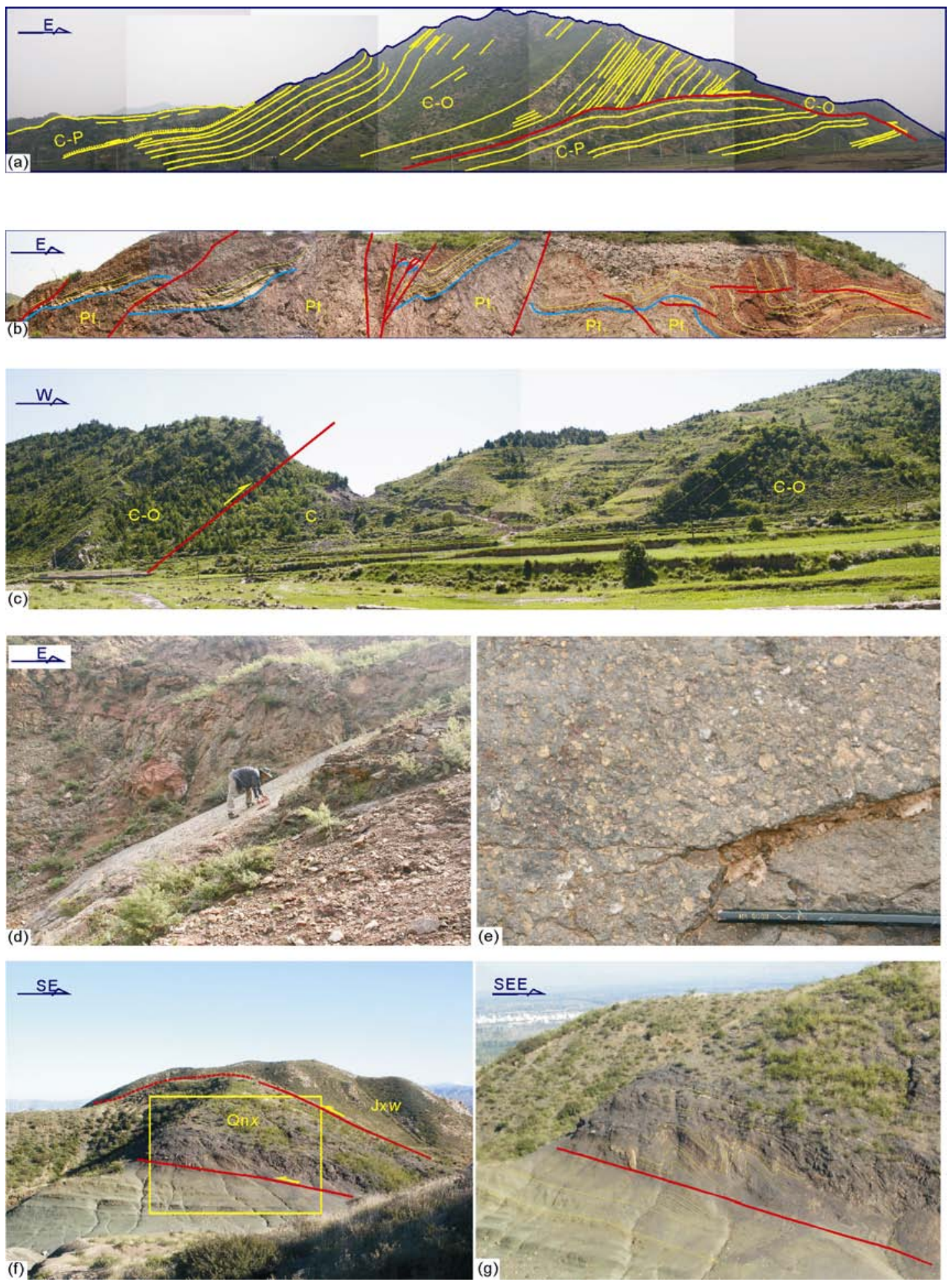

图 6 构造照片

(a) 大同西部大峪口-鹅毛口逆冲断层中的下盘断坡-断坪与残余断弯褶皱构造; (b) 大同西部大峪口-鹅毛口逆冲断层南段元古界基底卷入逆 冲变形及相关褶䏢构造; (c) 宁武-静乐向斜北西翼东寨-温岭逆冲构造(DWT), 寒武-奥陶系逆冲于石炭系煤系地层之上; (d) 山西忻州东南部 系舟山逆冲构造上盘中的次级断层; (e) 山西忻州东南部系舟山逆冲构造上盘沿次级断层分布的绿泥石化角砾岩; (f) 冀西北下花园-麻峪口 逆冲断层上盘中的次级逆冲构造, 蓟县系雾迷山组 $(\mathrm{Jx} w)$ 逆冲于青白口系下马岭组 $(\mathrm{Qn} x)$ 之上; (g), (f) 逆冲断层附近的褶皱变形 
东带分布在太行山东麓, 包括太行山中南部的 晋-获断裂、曲阳-唐县和易县一带西南部的逆冲构造 以及北京西山的逆冲构造, 向北一直可以追索到京 北怀柔西北部和冀北赤城东南部一带(图 1). 该带的 收缩变形中, 北京西山的逆冲构造曾经得到众多学 者的关注和研究, 而在太行山东麓的构造研究更多 关注的是所谓太行山山前断裂 ${ }^{[71,85,86]}$, 对该区域的收 缩构造变形研究相对较少 ${ }^{[87]}$. 研究发现, 在易县西部 及北京西山地区的逆冲构造主要表现为自 SE 向 NW 的逆冲作用及伴生的褶皱变形, 但是, 在曲阳北部和 唐县西部一带, 至少存在着自南向北的逆冲、NW-SE 向缩短导致的基底卷入式褶皱变形和逆冲构造以及 自北西向南东的褶皱后逆冲构造(图 1). 太行山东麓 收缩构造带往北, 经北京西山妙峰山一带的曹家堡黄土梁逆冲断层(CHT), 可以延伸到北京北部的昌平 十三陵-上庄-怀柔红螺寺逆冲构造(SSHT)、汤河口逆 冲构造(THT)、沙梁子逆冲构造(SLT)和千家店逆冲构 造(QJT). 而北京西山八宝山-南大寨逆冲构造(BNT), 向北东延伸应该可以与蓟县断裂 (JXF)相连(图 1), 它 们共同构成了华北-渤海湾新生代盆地西缘的晚中生 代逆冲构造系统.

\subsection{2 燕山东段}

在冀辽省界附近, 由近东西向延伸的燕山中段 向 NE 向展布的燕山东段过渡区域, 发育一系列 NE 向基底卷入式逆冲构造变形—大杖子-三道河-雱 神庙逆冲断层系统, 它们导致长城系和部分蓟县系 地层发生三重重复(图 2).

辽西地区的 NE 向收缩变形, 在北西侧表现为基 底卷入式逆冲变形, 往南东则主要表现为发育在盖 层内部的逆冲断层和褶皱构造. 主要逆冲断层包括 杨杖子-瓦房店逆冲构造(YWT)、河坎子-南公营子汤神庙逆冲构造(HNT) 以及建昌-朝阳-北票逆冲构造 系统 (JCBT) ${ }^{[30]}$ (图 1). 这些逆冲构造都表现为自北西 向南东的逆冲作用, 卷入变形的最新地层是位于北 票东部的晚白严世孙家湾组, 侵入切穿逆冲断层的 黑山岩体显示逆冲变形结束于 $116 \mathrm{Ma}$ 以前 ${ }^{[30]}$.

凌源南部瓦房店一带地层与构造形迹保存相对 完好, 而且其中所包含的构造变形信息在辽西地区 具有比较好的代表性, 因此在该区域开展了比较详 细的地质填图(图 5).

区内代表性的构造形迹主要有 NE 向展布的逆
冲断层、逆冲断层相关的褶皱构造以及被改造的控制 白严纪断陷盆地的高角度正断层系. 主要逆冲断层 是区域上杨杖子-瓦房店逆冲系(YWT)的一部分(图 1), 长城系和部分藓县系地层沿着它向 SE 逆冲于古生界 及上覆郭家店组和邓杖子组之上, 逆冲系统在西部 和北部被义县组火山岩(123 124 Ma $)^{[30,88]}$ 所覆盖. 图 区中北部上白尺沟到哈叭气一带的复式箱状背斜由 3 个次级背斜组成, 且在背斜核部发育有 4 条逆冲断层, 其中以发育在上白尺沟到哈叭气西北部的逆冲断层 (TF2) 规模较大(图 5). 这些逆冲断层从蓟县系雾迷山 组或铁岭组开始发育, 向上扩展终止于新元古界青 白口系顶部. 位于孟杖子-王木匠沟南东侧的逆冲断 层(TF3)的规模和地层效应表明它可能是上盘向南东 逆冲断层(TF4)的反冲断层, 它们之间的所夹持的部 分地层显示出冲起构造组合样式(图 5), 这些特征显 示该背斜可能具有断展褶皱变形属性.

需要指出的是, 在图区中部大榆树林-沈家屯-榆 树底下北部一带, 亦即大致沿 $\mathrm{AB}$ 剖面线位置, 发育 有一被 NE-NNE 向褶皱和逆冲断层改造的早期 NWW-WE 向背斜构造. 该背斜位于杨杖子-瓦房店 逆冲断层(YWT)上盘的部分, 核部由长城系高于庄 组组成, 且在井上村西部呈现为向南倒转的背斜(图 5). 位于杨杖子-瓦房店逆冲断层下盘的部分, 背斜 核部地层为蓟县系雾迷山组, 其总体轮廓可由青白 口系的分布状况大致反映出来, 只是由于后期 NNE 向逆冲作用和褶皱的改造而变得较为复杂. 与该早 期 NWW 向背斜对应的向斜位于郭杖子-北庄户-牛营 子一带, 核部最新地层为二叠系, 被主干低角度逆冲 断层所压盖, 转折端在牛营子东南部的红石砬山保 存完好(图 5). 上述两个不同方向构造之间的叠加改 造关系表明, NWW 向构造形成早于 NE 向构造变形. 区内地层产状赤平投影统计结果(图 7)比较好地反映 了区内 NE-NNE 向展布的收缩变形(图 7(a)浅色阴影 拟合区), 被改造的早期 NWW 向构造亦有较好显示 (图 7(a)深色阴影拟合区).

\section{3 收缩构造变形时间}

以脆性变形为主的太行山北部和燕山地区的收 缩变形时代, 主要是在确定了变形与相关地质体(火 山岩和/或侵入岩)相互关系的基础上, 通过测定这些 相关地质体的时代间接确定. 对于韧性变形构造, 可 

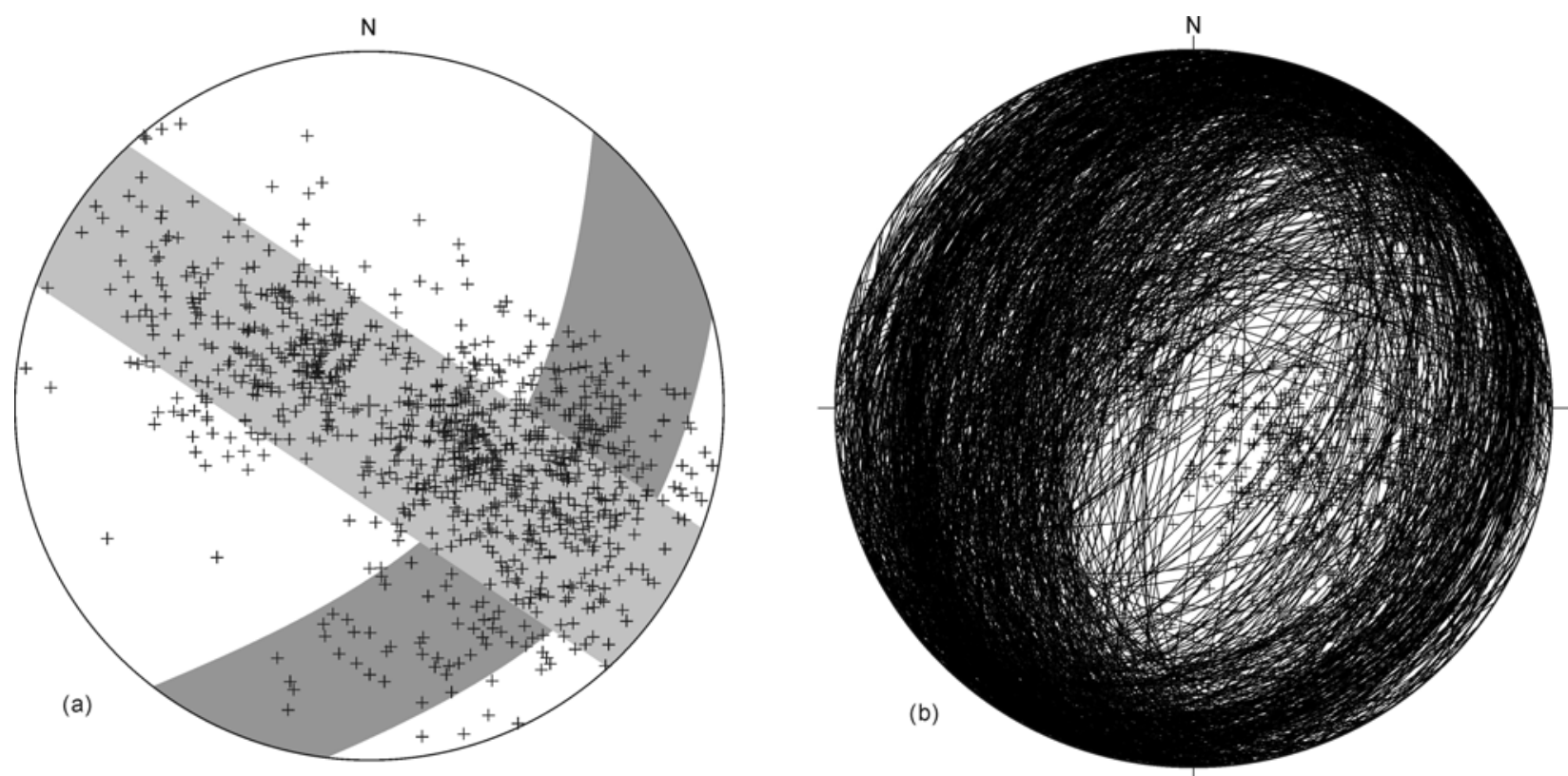

图 7 凌源瓦房店一带变形地层产状赤平投影统计图

下半球投影, 969 组层面产状; (a) 层面极点投影图; (b) 层面投影

通过直接测定同变形矿物的同位素年龄来限定其形 成时代. 近年来, 在燕山地区和太行山北部进行的大 量同位素地质年代学测定工作, 比较好地限定了部 分收缩构造变形的时代(表 1). 而另一些逆冲构造, 目前只能根据卷入变形的相关地层的时代做出定性 的判定.

从表 1 中已有较好年代学限定的逆冲构造可以 看出, 燕山和太行山地区的收缩构造变形在古生代 末、三叠纪、侏罗纪到早白严世超过 $130 \mathrm{Ma}$ 的时间 内均有发生. 具有确切时代限定的三叠纪逆冲构造 目前仅见于辽西凌源南部, 并且先后具有大致相反

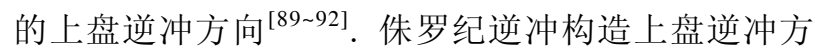
向比较复杂, 总体上表现为早-中侏罗世以南北向缩 短变形为主, 如燕山中部的清水湖-上庄子逆冲断层 $(\mathrm{QST})$ (图 2)、下店子-平泉逆冲断层 $(\mathrm{XPT})($ 图 1 和 2) 和辽西喀左窟窟山逆冲构造等, 但同时有反映 NE-SW 向缩短的冷口逆冲断层(LKF)(图 1 和 2)发育. 晚侏罗世既有指向 NNW 的逆冲构造, 如承德逆冲断 层(CDT)(图 1 和 2), 亦存在倒向 SW 的褶皱与逆冲构 造一云蒙山倒转褶皱和逆冲构造. 晚侏罗世-早白 严世早期的逆冲构造显示存在近南北向和 NW-SE 向 双重收缩变形. 本次研究中, 运用锆石 $\mathrm{U}-\mathrm{Pb}$ 离子探
针(SHRIMP)测年方法, 通过对卷入易县西部清西陵 一带 NE 向褶皱和逆冲构造变形的火山岩((137 \pm 2$)$ $\mathrm{Ma})$ 以及穿切褶皱及逆冲构造的旺隆水库石英闪长

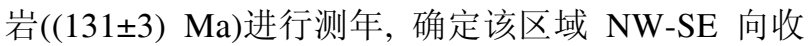
缩变形发生于 137 131 Ma 期间. 早白严世中期以 NW-SE 向收缩变形为主, 只是在阜平隆起中南部见 有 NNE-SSW 向缩短产生的逆冲构造, 如孟家台-南 台逆冲断层(MNT). 由于该逆冲构造切穿了麻棚岩

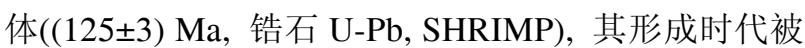
确定为 $125 \mathrm{Ma}$ 之后.

太行山北部及燕山西段的一系列主要反映 NW-SE 向缩短的逆冲构造和褶皱变形, 目前只能根 据其中卷入变形的地层时代推测它们的形成时代在 中晚侏罗世之后, 早白严世(东岭台组)之前(表 2 和图 $1)$.

\section{4 收缩变形对浅层地壳加厚的影响}

为了定量和半定量地估算收缩变形所造成的浅 部地壳缩短和加厚效应，我们编制完成了辽西凌源 南部瓦房店的局部构造剖面以及燕山中部的南北向 剖面并进行线长平衡复原，以了解和评估 $\mathrm{NE}$ 向收缩 构造变形与近 WE 向收缩构造变形所反映的缩短量. 
表 1 燕山太行山北部地区已有同位素年代学资料限定的逆冲构造与区域性褶皱变形

\begin{tabular}{|c|c|c|c|c|}
\hline 时代 & 逆冲构造名称及代号 & 形成时代(Ma) & 逆冲方向 & 年龄资料来源 \\
\hline \multirow{6}{*}{$\mathrm{K}_{1}^{2}$} & 孟家台-南台逆冲断层(MNT) & $125-$ & NNE & 本文, 说明见正文 \\
\hline & 建昌-朝阳-北票逆冲构造(JCBT) & $136 \sim 116$ & SE & {$[30,93]$} \\
\hline & 曹家堡-黄土梁逆冲断层(CHT) & $138 \sim 118$ & NW & [78] \\
\hline & 下花园-麻峪口逆冲系(XMT) & $130-$ & NW & {$[32,94]$} \\
\hline & 汤河口逆冲构造(THT) & $136-$ & NW & [93] \\
\hline & 易县西陵褶皱及逆冲构造 & $137 \sim 131$ & NW & 本文, 说明见正文 \\
\hline \multirow{8}{*}{$\mathrm{J}_{3}-\mathrm{K}_{1}{ }^{1}$} & 四合堂褶皱推覆体与密云水库韧性逆冲断层(SHT) & $143 \sim 127$ & $\mathrm{~S}$ & {$[77,78]$} \\
\hline & 承德逆冲断层 $(\mathrm{CDT})$ & $153 \sim 135$ & NNW & {$[80,95,96]$} \\
\hline & \multirow{2}{*}{ 承德向斜(CDS) } & $147 \sim 136$ & & {$[93,97]$} \\
\hline & & $153 \sim 135$ & & [96] \\
\hline & 河坎子-南公营子逆冲构造(HNT) & $153 \sim 136$ & SE & {$[93,97]$} \\
\hline & 古北口-平泉断裂(GPF)(中段) & $148 \sim 132$ & $\mathrm{~S}$ & [78] \\
\hline & 八宝山-南大寨逆冲断层(BNT) & $157 \sim 128$ & NW & {$[78,98]$} \\
\hline & 杨杖子-瓦房店逆冲构造(YWT) & $162 \sim 124$ & SEE & {$[30,88]$} \\
\hline \multirow{10}{*}{$\mathrm{J}$} & 云蒙山倒转褶皱和逆冲构造 & $151 \sim 143$ & SW & {$[77,78]$} \\
\hline & 十三陵-红螺寺逆冲构造(SHT) & $161 \sim 151$ & NNW & {$[77,78]$} \\
\hline & 兴隆逆冲断层(XLT) & $>148$ & NNW & {$[44,78]$} \\
\hline & 清水湖-上庄子逆冲断层 $(\mathrm{QST})$ & $>158 \sim 160$ & $\mathrm{~S}$ & [99] \\
\hline & 下店子-平泉逆冲断层(XPT) & $>161$ & S & [96] \\
\hline & 尚义-赤城韧性剪切带 & 163 & $\mathrm{~S}$ & [35] \\
\hline & 冷口断裂 $(\mathrm{LKF})$ & $174 \sim 168$ & $\mathrm{NE}$ & {$[100]$} \\
\hline & 辽西喀左窟㶻山逆冲构造 & $>173$ & SSE & {$[78,101]$} \\
\hline & \multirow{2}{*}{ 未名逆冲断层 } & $>180$ & \multirow{2}{*}{$S$} & [78] \\
\hline & & $197 \sim 180$ & & [96] \\
\hline \multirow{2}{*}{$\mathrm{T}$} & \multirow{2}{*}{ 辽西凌源水泉沟逆冲构造 } & $<230$ & SEE & [89 92] \\
\hline & & $>230$ & $\mathrm{~W}$ & {$[89,92]$} \\
\hline $\mathrm{P}$ & 尚义-赤城㓞性剪切带 & 263 & $\mathrm{~S}$ & {$[36]$} \\
\hline
\end{tabular}

表 2 燕山-太行山北部地区仅有地质学资料限定的逆冲构造与区域性褶皱变形

\begin{tabular}{ccc}
\hline 逆冲构造名称及代号 & 卷入变形最新地层及时代 & 逆冲方向 \\
\hline 南阳寨-陈家庄逆冲断层 $(\mathrm{NCT})$ & 土城子组 $\left(\mathrm{J}_{3}\right)$ & $\mathrm{SE}$ \\
水堡逆冲断层 $(\mathrm{ST})$ & 土城子组 $\left(\mathrm{J}_{3}\right)$ & $\mathrm{NE}$ \\
小蒜沟-非菜沟逆冲带 $(\mathrm{XJT})$ & 土城子组 $\left(\mathrm{J}_{3}\right)$ & $\mathrm{NW}$ \\
大峪口-鹅毛口逆冲系(DET) & 云冈群 $\left(\mathrm{J}_{2}-\mathrm{K}\right)$ & $\mathrm{NW}$ \\
榆湾-芦草沟逆冲系(YLT) & 安定群 $\left(\mathrm{J}_{2}\right)$ & $\mathrm{SE}$ \\
杜家村-庄旺逆冲系(DZT) & 安定群 $\left(\mathrm{J}_{2}\right)$ & $\mathrm{SE}$ \\
神山-白草沟逆冲系(SBT) & 安定群 $\left(\mathrm{J}_{2}\right)$ & $\mathrm{SE}$ \\
娄烦-娘神庙逆冲系(LNT) & 安定群 $\left(\mathrm{J}_{2}\right)$ & $\mathrm{NW}$ \\
宁武-静乐向斜(NJS) & 安定群 $\left(\mathrm{J}_{2}\right)$ & \\
\hline
\end{tabular}

\section{1 辽西凌源南部的收缩变形}

辽西地区总体构造线走向为 NE-NNE(图 1), 其 中发育一系列重要的逆冲构造 ${ }^{[46,47,30]}$ 及相关的褶皱 变形, 而且白严纪以来的伸展变形广泛发育. 由于晚 中生代伸展变形的改造和破坏, 之前形成的构造形 迹与地层记录保存和暴露不全, 给平衡剖面的编制 带来较大困难. 为了初步了解 NE 向收缩构造变形所
造成的缩短与地壳加厚状况, 在辽西南部凌源瓦房 店一带详细填图(图 5)的基础上, 编制了两条 NWW 向贯穿性构造剖面(图 8). 在 AB 剖面上, 由于剖面西 端被九佛堂组和义县组覆盖区缺乏必要的构造几何 学限制, 因此仅对其中地表地质研究能够较好构建 几何学格架的部分进行线长平衡复原. 复原部分的 变形剖面现长约 $16.63 \mathrm{~km}$, 复原后剖面长度约 34.11 


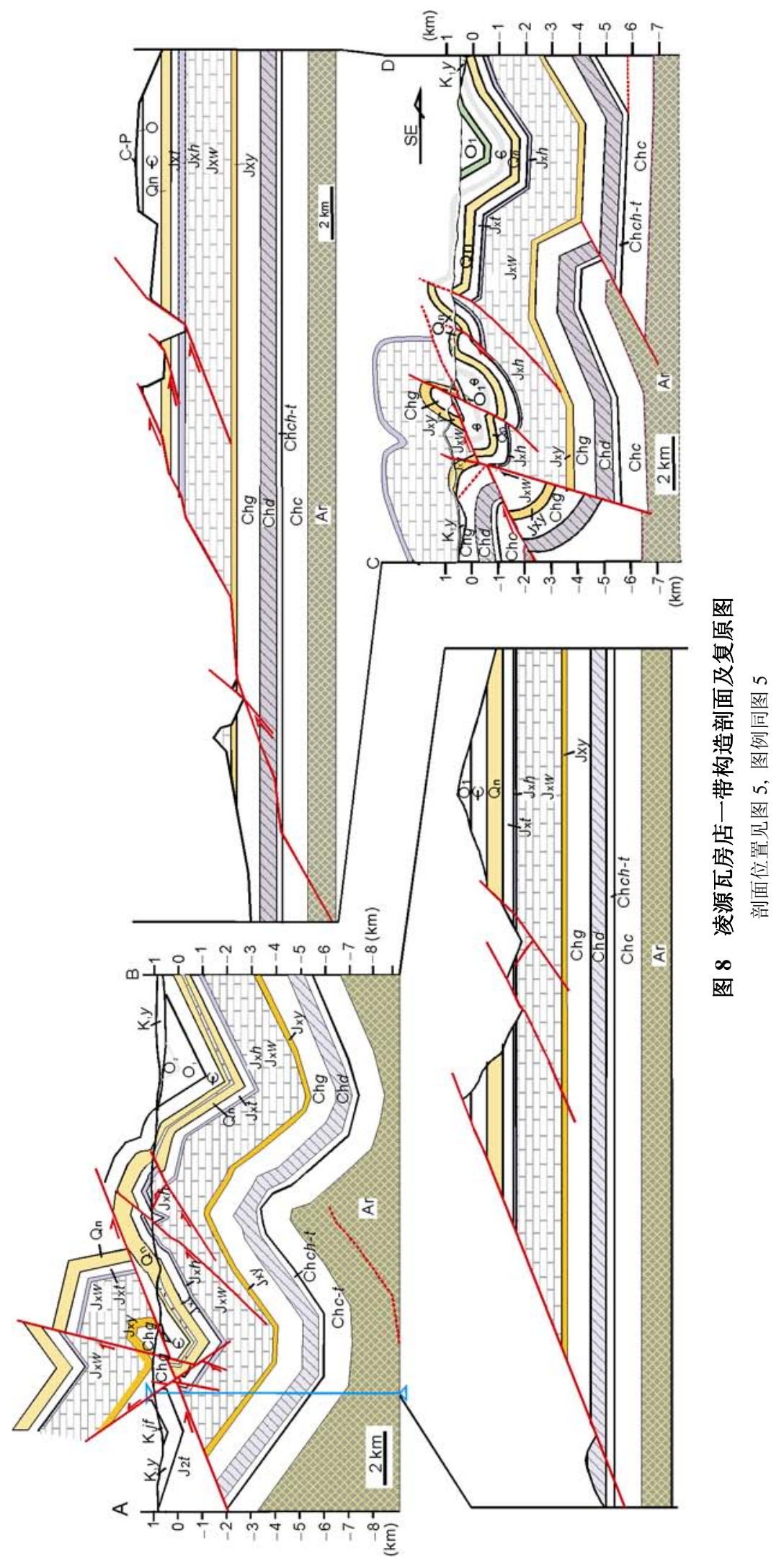


$\mathrm{km}$, 缩短率约 $51.25 \%$. 剖面 $\mathrm{CD}$ 变形后长度约 18.83 $\mathrm{km}$, 复原后长度约 $31.75 \mathrm{~km}$, 缩短率约 $41 \%$. 卷入上 述收缩变形的盖层地层厚度约 $6.9 \mathrm{~km}$, 如果上述缩 短变形都通过垂向加厚予以调节的话, 缩短变形可 使盖层加厚至 $11.6 \sim 14.2 \mathrm{~km}$, 加厚量约 $4.7 \sim 7.3 \mathrm{~km}$. 目前的研究尚未能够对早期 NWW-WE 向收缩变形 造成的缩短和加厚效应作出评估.

\section{2 燕山中部的近南北向收缩变形}

为了定量估算近 NS 向收缩变形所造成的水平缩 短与垂向加厚效应, 本次研究观测并编制完成了穿 越燕山中段主体部分的承德-丰润构造剖面, 并进行 了线长平衡复原(图 9). 复原部分现剖面长度约 148.4 $\mathrm{km}$, 复原剖面长度约 $239.1 \mathrm{~km}$, 缩短率为 $37.94 \%$.

在马兰峪背斜南翼, 密云-喜峰口断裂与古北口平泉断裂之间以及古北口-平泉断裂与承德逆冲断层 三个不同区段, 卷入逆冲变形的盖层地层厚度存在 差异, 在实际变形剖面当中(图 9(a))如实反映了这种 差异. 为了使剖面复原简化, 在复原图中没有反映这 种厚度变化. 卷入上述收缩变形的盖层地层厚度 $7.5 \sim 12.4 \mathrm{~km}$. 按照平均厚度为 $10 \mathrm{~km}$ 计, 如果收缩变 形导致的缩短被垂向地壳加厚所调节, 则仅盖层收 缩变形可以使地层柱加厚至约 $16.16 \mathrm{~km}$, 加厚幅度 约为 $6 \mathrm{~km}$.

需要指出的是, 这种缩短和加厚量的估算是比 较粗略的. 导致缩短量估算误差的因素主要包括以 下几个方面: 首先, 剖面尽管穿越了燕山造山带中段 的主体, 但是未能将一般所认为的燕山带的北 缘一一丰宁-隆化断裂编制在内. 沿丰宁-隆化断裂下 盘(南盘)分布的长城系地层序列和主要岩性, 完全可 以和承德南部的同时代地层对比, 只是地层厚度较 小 $^{[31]}$, 因此, 在丰宁-隆化断裂和承德逆冲断层以及 下店子-平泉断裂之间实际上是一个盖层被剥蚀掉的 基底卷入变形的大型背斜构造 ${ }^{[31]}$. 但是, 由于该区域 被剥蚀掉的部分在剖面上的位置缺乏应有的限定, 会给剖面的复原带来更大的不确定性，因此目前的 研究未将其计入在内. 这种处理可能导致缩短和加 厚量被明显低估. 其次, 在密云-喜峰口断裂和古北 口-平泉断裂之间，除了本文剖面上比较好地反映出 的收缩变形之外, 在剖面西侧的兴隆逆冲断层, 将太 古界深变质结晶岩系逆冲至石炭系煤系地层之上, 造成约 $13 \mathrm{~km}$ 的水平缩短 ${ }^{[84]}$, 缩短率达 $36.6 \%$, 造成
的局部地壳加厚幅度约为 $5.2 \mathrm{~km}$. 同时, 在剖面南段 东侧，马兰峪背斜核部向东延伸区域的 NW 向冷口 断裂，太古代结晶岩系逆冲至古生界地层之上，下盘 杨庄组泥质白云岩显示出显著的透入性韧性变形 ${ }^{[100]}$, 这种地层的和构造的变形效应都表明水平缩短与地 壳加厚是非常显著的. 但是, 上述变形尚未能反映在 贯穿性剖面所能够给出的缩短与加厚评估当中, 因 此, 目前所给出的估算可能明显小于实际的缩短与 加厚量. 第三, 上述加厚量估算并未将基底结晶变质 岩系卷入收缩变形的厚度计算在内. 如前所述, 燕山 和太行山北部的收缩变形, 具有基底和盖层岩系共 同卷入变形的特征, 但是已有研究仅初步厘定了盖 层收缩变形的基本格局，尚未查明基底结晶变质岩 系是如何响应和调节的. 从目前厘定的盖层变形构 造样式和卷入变形的地层厚度资料, 以及在兴隆县 挂兰峪乡东北部大青山一带马兰峪背斜核部常州沟 组的分布状况可以大致确定，燕山中段基底顶面埋 深高程差异达 $13 \mathrm{~km}$ (图 9(a)). 构造变形形迹及其运 动学特征显示这样大幅度的基底起伏不是由于伸展 变形所造成的，而是基底卷入式的大型褶皱和逆冲 作用的结果. 如果将卷入变形的基底部分的厚度计 算在内, 收缩变形导致的地壳加厚量将显著加大.

除了上述可能导致缩短量和加厚量低估的因素 之外, 估算过程中完全将水平缩短转换为垂向地壳 加厚，没有考虑侧向逃逸的影响可能会导致加厚量 的高估. 尽管沿着古北口-平泉断裂和密云-喜峰口断 裂发现有右行走滑构造活动 ${ }^{[102,103]}$, 但是现有研究尚 无证据表明南北向收缩变形期间存在大规模侧向物 质逃逸. 因此将缩短变形量转换为垂向加厚是基本 合理的.

\section{3 缩短变形可能导致的地壳加厚状况}

为了估算由卷入收缩变形的地壳厚度与缩短率 导致的最终地壳加厚状态，可采用图 10(a)所示水平 缩短完全由垂向增厚调节的简单图解. 其中, $H_{0}$ 为卷 入收缩变形的地壳厚度, $L_{0}$ 为变形前地壳长度, 变形 后长度为 $L_{1}, \Delta L$ 为缩短量, 缩短率 $\varepsilon_{\mathrm{s}}$ 为

$$
\varepsilon_{\mathrm{s}}=\Delta L / L_{1}=\left(L_{0}-L_{1}\right) / L_{0} \text {. }
$$

假定水平方向缩短量完全由垂向地壳加厚所调节, 导致的地壳加厚量为 $\Delta H$, 则

$$
\Delta H \times L_{1}=H_{0} \times \Delta L=H_{0} \times\left(L_{0}-L_{1}\right) .
$$

将式(1)代入式(2)可得 


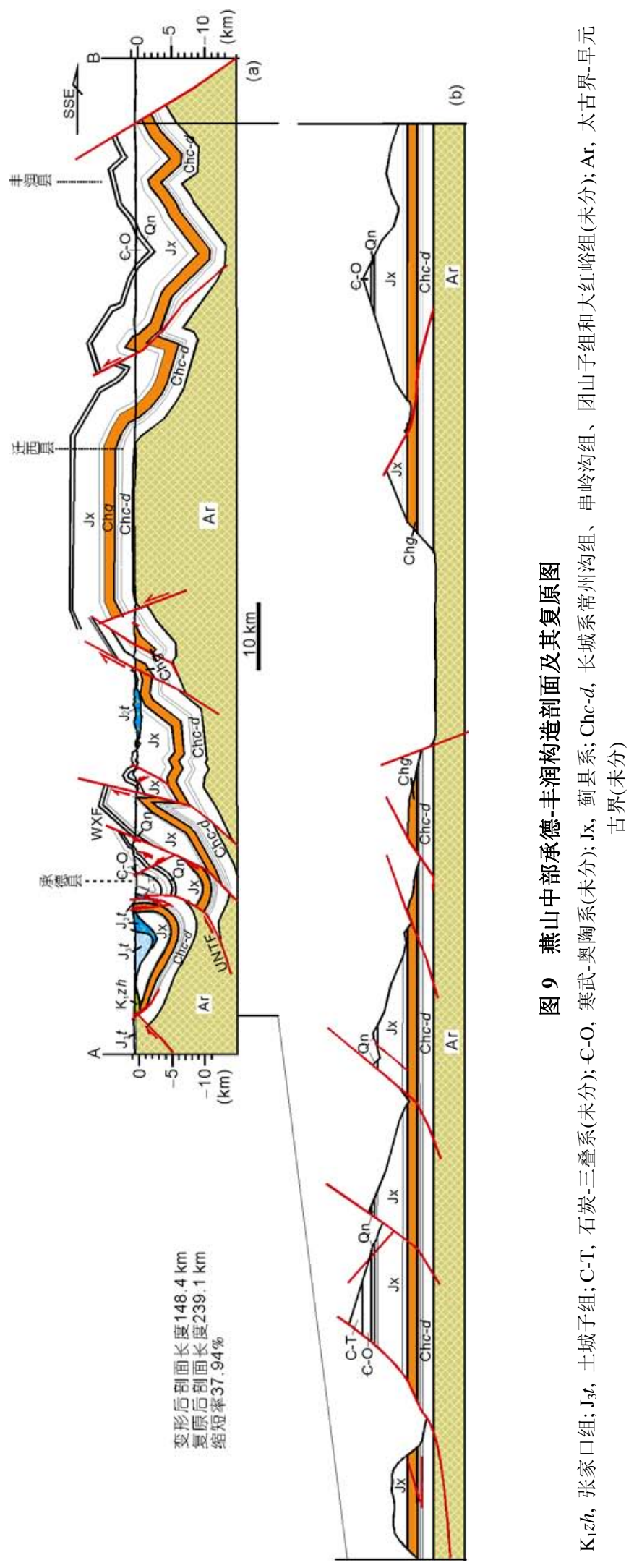




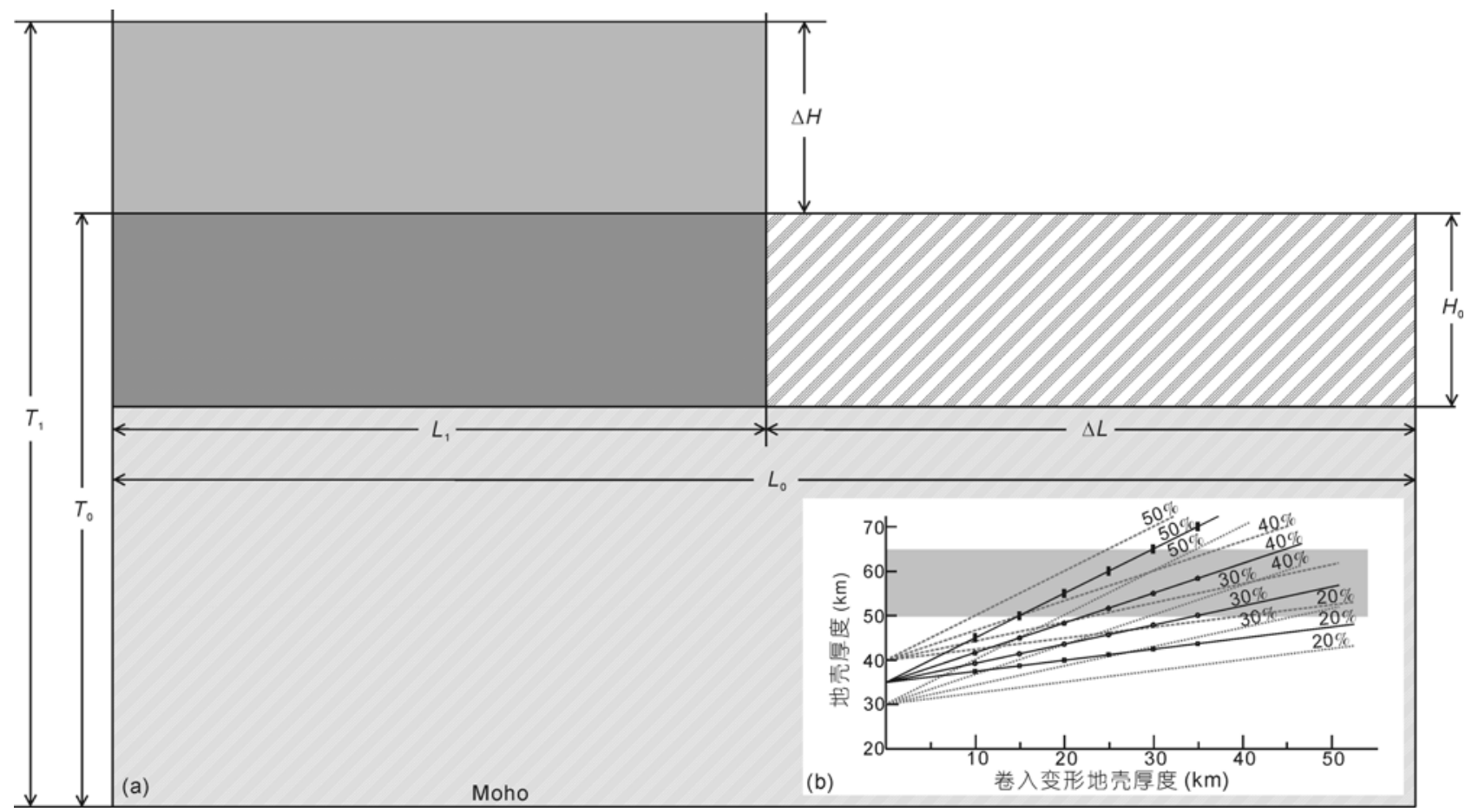

图 10 部分地壳卷入缩短变形导致地壳厚度增厚的计算图解(a)与不同初始地壳厚度和卷入变形地壳厚度随缩短率变化导致 的地壳加厚变化趋势(b)

(b)中阴影部分为下地壳榴辉岩化所需地壳厚度范围 ${ }^{[17,114,115]}$

$$
\Delta H=H_{0} \times\left[\varepsilon_{\mathrm{s}} /\left(1-\varepsilon_{\mathrm{s}}\right)\right] .
$$

变形后地壳厚度:

$$
T_{1}=T_{0}+\Delta H=T_{0}+H_{0} \times\left[\varepsilon_{\mathrm{s}} /\left(1-\varepsilon_{\mathrm{s}}\right)\right],
$$

$T_{0}$ 为变形前的地壳厚度. 由此, 可以根据变形前的地 壳厚度、卷入变形的地壳厚度和缩短率, 来估算由于 收缩变形导致的地壳加厚状态(图 10(b)).

高分辨率宽频地震观测揭示的燕山造山带现今 地壳厚度为 30 37 km ${ }^{[104]}$. 岩相古地理研究表明, 华 北东部中、晚石炭世-二叠纪早期属于浅海相沉积环 境, 二叠纪为海陆交互相沉积环境, 三叠纪已经完全

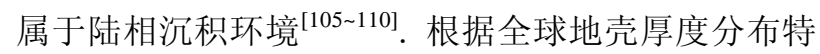
征 ${ }^{[111]}$ 和重力均衡大陆地壳厚度计算结果 ${ }^{[12,113]}$, 即 稳定大陆区域的地壳厚度大致为 $35 \sim 45 \mathrm{~km}$, 大陆边 缘地壳厚度 30 35 km, 海平面附近地壳厚度约 $30 \mathrm{~km}$, 推测在华北东部和燕山构造带发生强烈的收缩构造 变形之前的三叠纪时期地壳厚度约为 $35 \mathrm{~km}$. 沿尚义赤城断裂发现的晚古生代和中侏罗世角闪岩相韧性 逆冲变形 ${ }^{[33 \sim 36]}$ 以及晚中生代北京密云四合堂韧性逆 冲构造 ${ }^{[77,78]}$ 表明, 卷入燕山地区中生代收缩变形的 地壳厚度约有 $20 \sim 25 \mathrm{~km}$. 由此, 按照燕山中部的缩
短率可以计算得出, 收缩变形可能导致的地壳加厚 状态(47 50 km)(表 3), 已经接近下地壳榴辉岩化所 需地壳厚度 ${ }^{[17,114,115]}$. 如果将晚古生代时期“内蒙地

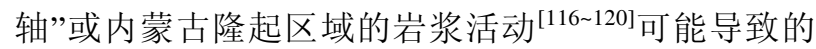
早期地壳加厚考虑在内, 或者根据路风香等 ${ }^{[18]}$ 估算 的中侏罗世髺䯽山组火山活动时的地壳厚度为 40 45 km, 而在髺髺山组火山活动之后区域上又发 生过强烈的收缩变形, 则中生代收缩变形导致的地 壳加厚状况, 有可能已经达到下地壳榴辉岩化所需 的地壳厚度.

\section{5 讨论}

\section{1 华北克拉通东部收缩变形后的构造属性}

收缩变形时-空分布特征及其可能造成的地壳水 平缩短与加厚评估表明, 晚古生代以来直到早白严 世早期, NNE 向的太行山北部和近东西向燕山构造 带, 甚至包括渤海湾-华北盆地北部在内 ${ }^{[121 ~ 123]}$, 共 同经受了近 NS 向和 NW-SE 向收缩变形, 并导致了 显著的地壳加厚. 因此, 从构造变形的角度看, 华北 
表 3 收缩变形可能导致的地壳加厚状态估算表

\begin{tabular}{ccccc}
\hline 缩短率 & 变形前地壳厚度 $(\mathrm{km})$ & 卷入变形地壳厚度 $(\mathrm{km})$ & 地壳加厚量 $(\mathrm{km})$ & 变形后地壳厚度 $(\mathrm{km})$ \\
\hline & 35 & 10 & 6 & 41 \\
& 35 & 15 & 9 & 44 \\
$37.94 \%$ & 35 & 20 & 12 & 47 \\
& 35 & 25 & 15 & 50 \\
& 35 & 30 & 18 & 53 \\
& 35 & 35 & 21 & 56 \\
\hline
\end{tabular}

克拉通此时已经明显失去了其本应有的稳定性. 这 种遭到初步破坏的构造状态, 在燕山地区曾被叫做

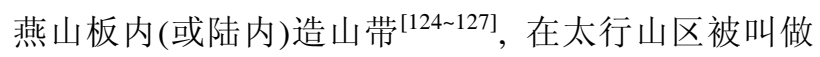
太行山构造带或太行山板内造山带 ${ }^{[128,129]}$. 重新厘定 的收缩构造变形特征和构造叠加特征显示, 它们尽 管在现今构造展布方向上存在差异, 但实际上, 至少 是太行山北部与燕山地区经历了相近的中生代收缩 变形过程.

近年来, 一些学者根据中生代岩浆岩地球化学 特征等研究, 提出中国东部曾经存在燕山晚期高原 的假说 ${ }^{[19 \sim 25,130,131]}$, 认为该高原的大规模抬升发生在 中-晚侏罗世期间, 在早白严世之后塌陷. 岩相古地 理研究早已揭示, 晚三叠世-侏罗纪期间中国东部曾 经存在一个华北高地, 并在不同阶段其分布范围在 发生逐渐变化 ${ }^{[106]}$, 但是是否曾经抬升很高成为高原, 还需要从多方位开展古高程的细致研究. 高原的隆 升机制和隆升过程问题目前仍然存在比较大的分歧, 但是, 高原具有异常厚的地壳已成为共识 ${ }^{[132]}$. 加厚 地壳的重力均衡、水平缩短导致的直接抬升、岩浆活 动导致的热隆升、岩石圈地幔移除(或拆沉)导致的均 衡回跳、中下地壳物质的侧向流动和地表过程导致的 表层物质迁移与重力均衡响应等, 都可能单独或联 合在高原抬升的过程中发挥作用 ${ }^{[12,133 \sim 139]}$. 华北北 部燕山构造带晚古生代以来, 尤其是三叠纪-白严纪 早期收缩变形导致的强烈地壳加厚, 与在此期间广 泛的岩浆活动可能产生的热隆升效应, 都是华北东 部晚中生代高原形成的有利因素. 亦即收缩变形研 究结果比较倾向于支持早白严世初期可能存在东部 高原的假说.

\section{2 收缩变形与晚中生代伸展变形的时-空与成因 关系}

太行山-燕山地区晚古生代-白严纪初强烈的收 缩变形之后, 发生了广泛的伸展构造变形. 除了已经
广受关注的、主要形成于 130 110 Ma 期间的变质核 杂岩构造 ${ }^{[77,78,140 \sim 148]}$ 以外, 在更广泛的区域内表现为 不同方向的高角度正断层及其所控制的断陷盆地. 沉积岩相分析表明, 伸展断裂控制的断陷盆地沉积 作用发生在九佛堂组沉积时期及其之后 ${ }^{[149 \sim 151]}$, 下伏 义县组(126 120 Ma) ${ }^{[152 \sim 154]}$ 和张家口组火山岩的分布 范围远大于这些地表伸展变形所控制的沉积作用范 围, 与主动裂谷作用模型 ${ }^{[155,156]}$ 预计的火山活动和伸 展变形地质事件序列类似. 华北克拉通北缘晚中生 代伸展构造, 是东亚晚中生代-新生代伸展构造的一 个重要组成部分 ${ }^{[60,143,157]}$. 它们的形成和演化无疑会 受到晚中生代以来东亚总体构造动力学背景和构造 体制的制约. 因此, 关于东亚晚中生代伸展构造形成 的动力学背景, 有学者主张是西太平洋俯冲带回撤 的结果 ${ }^{[157]}$, 另有学者认为兴蒙造山带东部到华北克 拉通北缘北部的晚中生代伸展构造是蒙古-鄂霍次克 带碰撞后洋壳板片断离和高原重力扩展的结果 ${ }^{[158]}$, 或者是岩石圈地幔拆沉所造成的 ${ }^{[146,147]}$. 但是, 区域 性的构造变形是直接反映了板块尺度的大区域构造 应力状况, 还是也可以由于区域性因素所引起, 仍需 进一步评价与甄别.

造山带伸展构造变形研究显示, 造山带收缩变形 导致地壳加厚, 又加厚地壳重力失稳和深部地壳物质 部分熔融又引发造山带地壳强度降低, 并最终导致造 山带的伸展垮塌和造山后岩浆活动, 是造山带逆冲构 造-岩浆活动-伸展构造发育过程的一般规律 ${ }^{[61,159]}$. 早 期地壳加厚和均衡抬升所产生的与周围非加厚地壳区 域之间的重力势能差, 完全可以成为伸展变形的主要 驱动力 ${ }^{[113,132,160,161]}$, 并且可以在区域板块构造背景和 应力体制不发生改变的情形下产生垮塌作用 ${ }^{[160,162]}$. 造山带地壳加厚达到正常大陆地壳厚度的两倍 ${ }^{[13]}$ 或 大于 $50 \mathrm{~km}$ 时 ${ }^{[132]}$, 即可产生足够的重力势能差, 并 驱动造山带发生伸展垮塌. 而且, 如果这种重力势能 差驱动的造山带或造山带型高原的垮塌同时伴有岩 
石圈地幔移除(removal)的联合作用, 则有可能使一 个造山带或造山带型高原最终形成地中海型弧后盆 地 $^{[113]}$. 如果造山带加厚地壳区域出现部分熔融, 则 更有利于造山带的伸展垮塌作用的产生 ${ }^{[162,163]}$.

因此, 从造山带构造变形的角度看, 燕山造山带 晚中生代伸展构造变形之前的地壳加厚, 为随后发 生的伸展构造变形奠定了物质基础和驱动力基础. 而在收缩变形期间不断发生的岩浆侵入和火山活动, 表明地壳在加厚期间始终处在深部热活动引起的强 度弱化过程中. 这两种因素的共同作用, 为触发加厚 地壳的伸展㘷塌做好了充分准备. 如果再加上区域 板块构造活动体制的改变导致维持地壳加厚状态的 应力场的变化, 则更易导致加厚地壳区域的垮塌作 用. 因此, 至少对于燕山和太行山北部区域的伸展构 造变形来说, 早期地壳加厚引发的伸展垮塌是不容 忽视的重要方面. 模拟研究表明, 影响造山带收缩与 伸展变形间隔时间长短的重要因素之一是 Moho 界面 的初始温度, 如果初始 Moho 界面温度超过 $700^{\circ} \mathrm{C}$, 那么一旦缩短作用停止, 随即发生伸展作用; 而当温 度低于 $450^{\circ} \mathrm{C}$ 时, 伸展作用滞后于收缩作用可达 100 $\mathrm{Ma}^{[164]}$. 燕山地区已有的部分研究表明, 收缩变形早 于伸展变形, 但时间间隔相对较短 ${ }^{[32,100,142]}$, 这可能 说明了燕山造山带晚中生代时期 Moho 面温度较高, 也暗示了深部热作用引起的地壳强度弱化更有利于 造山带的伸展垮塌的地壳状态.

\section{3 收缩变形对克拉通破坏方式与过程的启示}

对收缩变形产生的地壳缩短和加厚的估算表明, 太行山和燕山地区南北向收缩变形导致的地壳加厚 状态, 可能已经接近下地壳榴辉岩化并进一步诱发 下地壳拆沉作用所需要的地壳厚度 ${ }^{[114]}$. 因此, 收缩 变形为拆沉作用的发生奠定了关键基础. 另一方面, 缩短变形导致的地壳加厚幅度本身也为随后发生的 造山带重力垮塌奠定了基础. 从这个意义上讲, 深部 拆沉作用和浅部伸展垮塌, 都是早期地壳加厚的结 果, 伸展变形不必是拆沉作用的必然响应.

图 11 表示了基于收缩变形及其与其他地质作用 过程相互关系分析而建立的克拉通破坏过程, 表明 在晚三叠世到白严纪初期(230 135 Ma), 克拉通(燕 山-太行山北部)在原有稳定状态(图 11(a))基础上经受 了强烈的收缩变形和地壳加厚, 期间所发生的火山 活动和岩浆侵入及其岩石与地球化学特征表明在此
期间岩石圈可能已经在减薄, 因此是一个地壳加厚 和岩石圈减薄的过程, 并伴随有地表的较大幅度抬 升(图 11(b)). 135 120 Ma 期间, 即大致相当于张家口

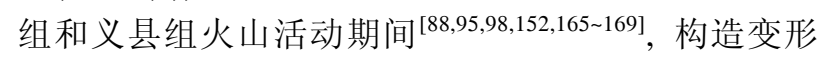
导致的地壳加厚基本结束, 岩石圈减薄持续发生, 地 壳加厚导致的均衡作用和热隆升共同作用使隆升达 到最大高度(图 11(c)). 120 65 Ma 期间, 相当于九佛 堂组及其上覆晚白严世地层沉积时期, 地壳表层发 育大范围断陷盆地和反映地壳强烈伸展变形的变质 核杂岩构造, 总体表现出盆一岭式伸展构造格局; 岩 石圈减薄至最大程度, 古老克拉通岩石圈地幔大多 被新生软流圈地幔取代, 稍早因地壳加厚形成的地 壳底部的榴辉岩部分拆沉进入软流圈当中(图 11(d)), 即在华北克拉通破坏过程中如果发生拆沉作用 ${ }^{[170]}$, 应该发生在这一时期. $65 \mathrm{Ma}$ 以来, 位于强烈减薄的 岩石圈下部的软流圈逐渐冷却形成新的岩石圈地幔, 在热沉降和岩石圈逐渐加厚引起的均衡作用的共同 影响下, 先期形成的盆-岭构造总体沉降拗陷, 形成 古近纪以来的渤海湾-华北盆地(图 11(e)).

从上述过程不难发现, 如果没有收缩变形导致 的缩短和地壳大幅度加厚, 则源于深部的、自下而上 的热-机械侵蚀或岩石圈地幔交代作用以及主动裂谷 式伸展构造变形, 可能在整个克拉通岩石圈的破坏 过程中占据更加重要和主动的地位, 但拆沉作用机 制难以发挥作用. 从对研究区域内收缩变形导致的地 壳加厚估算结果来看, 它为拆沉作用的发生创造了必 要条件, 且在早白严世之后发生拆沉作用的条件应该 更加充分, 之前的岩浆活动和岩石圈减薄则可能由热机械侵蚀或岩石圈地幔交代作用主导. 收缩变形和地 壳加厚幅度不仅可能已经达到足以触发拆沉作用的 程度, 而且也已经达到促使造山带伸展垮塌发生所 需的壳厚度状态, 所以深部拆沉作用和浅部重力垮 塌与伸展变形构成了整个克拉通破坏过程中的两个 方面，伸展变形不是拆沉作用的必然响应.

\section{6 结论}

燕山-太行山中生代收缩构造变形主要表现为基 底卷入的逆冲构造、基底为核的大型纵弯褶皱构造以 及韧性逆冲推覆构造. 构造形迹展布方向主要有近 WE 向-NWW 向和 NE-NNE 向. 在总体构造线呈 NNE 向展布的太行山构造带和辽西燕山东段, 也发现有近 


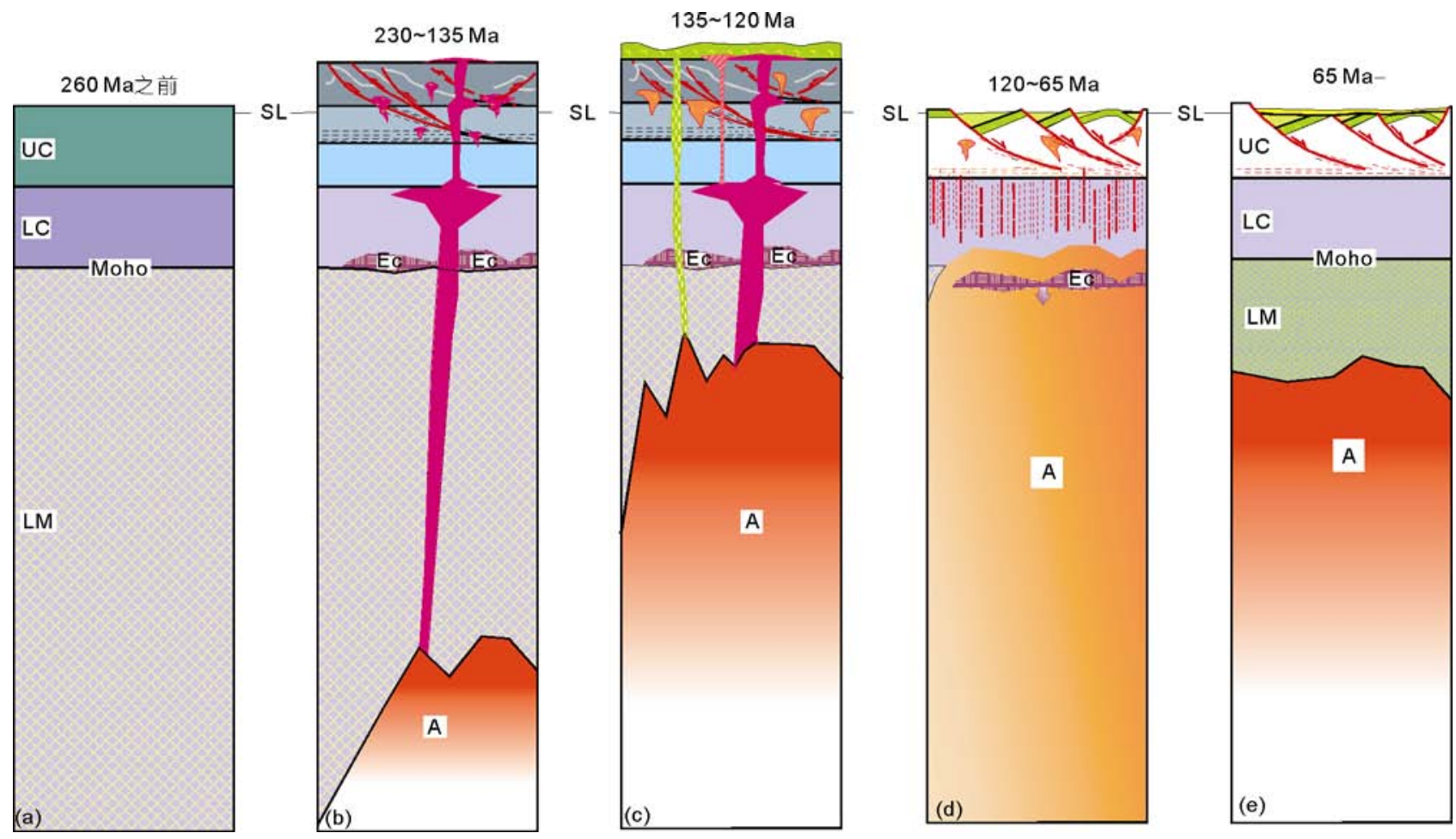

图 11 克拉通破坏过程卡通图解

$\mathrm{UC}$, 上地壳; LC, 下地壳; LM, 岩石圈地幔; A, 软流圈; Ec, 榴辉岩; SL, 海平面(只具参考意义, 未按比例标示海平面上、下垂向涉及的实际 范围)

WE 向和 NWW 向收缩构造变形发育. 收缩变形在古 生代末、三叠纪、侏罗纪到早白严世超过 $130 \mathrm{Ma}$ 的时 间内均有发生. 同时代逆冲构造, 尤其是侏罗纪期间 的逆冲构造, 走向和上盘逆冲方向并未表现出一致性.

燕山中部主体近南北向缩短的构造剖面复原显 示缩短率约为 38\%. 如果根据华北东部晚古生代和 早中生代岩相古地理研究成果所推测的强烈收缩变 形前的地壳厚度为 $35 \mathrm{~km}$, 将韧性剪切收缩变形反映 的变形深度 $(20 \sim 25 \mathrm{~km})$ 作为卷入收缩变形的地壳厚 度, 并假设水平缩短变形由垂向地壳加厚所调节, 则 仅南北向缩短所造成的地壳加厚状态(47 50 km), 已 经接近拆沉构造模型中下地壳榴辉岩化所需的地壳 厚度. 同时, 加厚地壳均衡抬升产生的重力势能差, 与地壳加厚期间持续不断的岩浆活动导致的岩石圈 强度弱化, 为在区域构造应力状态不发生改变的情
形下发生中浅部地壳的伸展垮塌创造了充分条件.

燕山-太行山中生代收缩构造变形研究表明, 收 缩变形一方面直接导致了克拉通岩石圈浅层稳定状 况的破坏, 另一方面也为深部拆沉作用的发生创造 了必要条件, 并为通过重力垮塌方式产生浅部伸展 变形提供了充分条件. 华北克拉通的破坏, 经历了稳 定的克拉通-收缩变形导致的克拉通破坏(形成克拉 通内造山带或高原)-伸展变形和强烈的岩浆活动-最 终导致克拉通破坏 (失去稳定性)的过程. 在具有上述 早期地壳加厚状态下的克拉通破坏过程中，拆沉作 用和伸展垮塌是地壳加厚达到一定程度和破坏过程 持续进行时的两个方面. 在没有早期地壳加厚的情 况下，克拉通破坏过程中伸展变形仍然可以发生，而 拆沉作用则不具备发生条件. 因此, 不宜将浅层伸展 变形作为深部拆沉作用曾经发生的直接构造证据. 
1 吴福元, 葛文春, 孙德有, 等. 中国东部岩石圈减薄研究中的几个问题. 地学前缘, 2003, 10: 51-60

2 吴福元, 徐义刚, 高山, 等. 华北岩石圈减薄与克拉通破坏研究的主要学术争论. 岩石学报, 2008, 24: 1145-1174

3 Deng J F, Mo X X, Zhao H L, et al. A new model for the dynamic evolution of Chinese lithosphere: Continental roots-plume tectonics. Earth-Sci Rev, 2004, 65: 223-275

4 Deng J F, Su S G, Niu Y L, et al. A possible model for the lithospheric thinning of North China Craton: Evidence from the Yanshanian (Jura-Cretaceous) magmatism and tectonism. Lithos, 2007, doi: 10.1016/j.lithos.2006.09.009

5 周新华. 中国东部中、新生代岩石圈转型与减薄研究的若干问题. 地学前缘, 2006, 13: 50-54

6 朱日祥. 地球内部结构探测研究——以华北克拉通为例. 地球物理学进展, 2007, 22: 1090-1100

7 Menzies M A, Xu Y G, Zhang H F, et al. Integration of geology, geophysics and geochemistry: A key to understanding the North China Craton. Lithos, 2007, 96: 1-21

8 Zhai M G, Fan Q C, Zhang H F, et al. Lower crustal processes leading to Mesozoic lithospheric thinning beneath eastern North China: Underplating, replacement and delamination. Lithos, 2007, 96: 36-54

9 徐义刚. 岩石圈的热-机械侵蚀和化学侵蚀与岩石圈减薄. 矿物岩石地球化学通讯, 1999, 18: 125

10 Xu Y G, Chung S L, Ma J, et al. Contrasting Cenozoic lithospheric evolution and architecture in western and eastern Sino-Korean Craton: Constraints from geochemistry of basalts and mantle xenoliths. J Geol, 2004, 112: 593-605

11 许文良, 王清海, 王冬艳, 等. 华北克拉通东部中生代岩石圈减薄的过程与机制: 中生代火成岩和深源捕虏体证据. 地学前缘, 2004, 11: 309-317

12 杨进辉, 吴福元. 华北东部三叠纪岩浆作用与克拉通破坏. 中国科学 D 辑：地球科学, 2009, 39: 910-921

13 翟明国, 孟庆任, 刘建明. 华北东部中生代构造体制转折峰期的主要地质效应和形成动力学探讨. 地学前缘, 2004, 11: 285-298

14 徐义刚, 李洪颜, 庞崇进, 等. 论华北克拉通破坏的时限. 科学通报, 2009, 54: 1974-1989

15 Wu F Y, Walker R J, Yang Y H, et al. The chemical-temporal evolution of lithospheric mantle underlying the North China Craton. Geochim Cosmochim Acta, 2006, 70: 5013-5034

16 路风香, 郑建平, 邵济安, 等. 华北东部中生代晚期-新生代软流圈上涌与岩石圈减薄. 地学前缘, 2006, 13: 86-92

17 邓晋福，苏尚国，赵海玲，等. 华北地区燕山期岩石圈减薄的深部过程. 地学前缘, 2003, 10: 41-50

18 路风香, 郑建平, 张瑞生, 等. 地壳与弱化岩石圈地幔的相互作用: 以燕山造山带为例. 地球科学一中国地质大学学报, 2006, 31: $1-7$

19 张旗, 王焰, 钱青, 等. 中国东部燕山期埃达克岩的特征及其构造-成矿意义. 岩石学报, 2001, 17: 236-244

20 张旗, 王焰, 王元龙. 燕山期中国东部高原下地壳组成初探: 埃达克质岩 Sr、Nd 同位素制约. 岩石学报, 2001, 17: 505-513

21 张旗, 李承东, 王焰, 等. 中国东部中生代高 $\mathrm{Sr}$ 低 $\mathrm{Yb}$ 和低 $\mathrm{Sr}$ 高 $\mathrm{Yb}$ 型花岗岩: 对比及其地质意义. 岩石学报, 2005, 21: 1527-1537

22 张旗, 金惟俊, 王元龙, 等. 晚中生代中国东部高原北界探讨. 岩石学报, 2007, 23: 689-700

23 张旗, 王元龙, 金惟俊, 等. 早中生代的华北北部山脉: 来自花岗岩的证据. 地质通报, 2008, 27: 1391-1403

24 张旗, 王元龙，金惟俊，等. 晚中生代中国东部高原：证据、问题和启示. 地质通报, 2008, 27: 1404-1430

25 张旗, 金惟俊, 李承东, 等. 中国东部燕山期大规模岩浆活动与岩石圈减薄: 与大火成岩省的关系. 地学前缘, 2009, 16: 21-51

26 Davis G A. The Yanshan belt of northern China: Tectonics, adakitic magmatism, and crustal evolution. Earth Sci Front, 2003, 10: 373-384

27 Xu W L, Gao S, Wang Q H, et al. Mesozoic crustal thickening of the eastern North China Craton: Evidence from eclogite xenoliths and petrologic implications. Geology, 2006, 34: 721-724

28 王国灿, 谭应佳, 王方正. 冀北崇礼-赤城断裂的多相逆冲. 地球科学, 1992, 17: 621-630

29 贾建称. 冀北丰宁-隆化深断裂带的基本特征和演化历史. 河北地质学院学报, 1995, 18: 334-340

30 张长厚, 王根厚, 王果胜, 等. 辽西地区燕山板内造山带东段中生代逆冲推覆构造. 地质学报, 2002, 76: 64-76

31 张长厚, 吴洤国, 徐德斌, 等. 燕山板内造山带中段中生代构造格局与构造演化. 地质通报, 2004, 23: 864-875

32 张长厚, 张勇, 李海龙, 等. 燕山西段及北京西山晚中生代逆冲构造格局及其地质意义. 地学前缘, 2006, 13: 165-183

33 李龙, 孙恺蒜, 胡玲, 等. 尚义-赤城断裂带西段韧性变形研究. 地球科学——中国地质大学学报, 1995, 20(增刊 II ): 33-37

34 温长顺, 胡建中, 白志达, 等. 尚义-赤城断裂带的构造特征与演化. 地球科学一一中国地质大学学报, 1995, 20(增刊 II ): 15-20

35 王瑜. 中国东部内蒙古-燕山造山带晚古生代晚期-中生代的造山作用过程. 北京：地质出版社, 1996.1-143

36 胡玲, 宋鸿林, 颜丹平, 等. 尚义-赤城断裂带中糜棱岩 ${ }^{40} \mathrm{Ar} \mathrm{r}^{39} \mathrm{Ar}$ 年龄记录及其地质意义. 中国科学 $\mathrm{D}$ 辑: 地球科学, 2002, 32: 908-913

37 徐德斌, 胡建中, 李志忠. 河北尚义中生代盆地后城组沉积环境分析. 地球科学——中国地质大学学报, 1995, 20(增刊 II ): 51-56

38 胡建中, 徐德斌, 李志忠, 等. 陆相盆地沉积旋回、沉积体系、地层界面与岩石地层单位之间的关系研究一以冀西北土木路中生 
代断陷盆地为例. 地球科学——国地质大学学报, 1995, 20(增刊 II ): 38-44

39 和政军, 李锦轶, 牛宝贵, 等. 燕山-阴山地区晚侏罗世强烈推覆-隆升事件及沉积响应. 地质论评, 1998, 44: 407-418

40 和政军, 王宗起, 任纪舜. 华北北部侏罗纪大型推覆构造带前缘盆地沉积特征和成因机制初探. 地质科学, 1999, 34: 186-195

41 何政军, 牛宝贵, 张新元. 冀西北尚义盆地对晚侏罗世构造活动的沉积响应. 中国地质, 2008, 35: 181-195

42 姜波, 王桂梁, 刘洪章, 等. 河北兴隆复式叠瓦扇构造. 地质科学, 1997, 32: 165-172

43 刘天林, 李涛. 兴隆矿区外围推覆构造及煤田预测. 煤田地质与勘探, 1992, 20: 1-8

44 张长厚, 陈爱根, 白志达. 河北省兴隆煤田及邻区厚皮式逆冲推覆构造与隐伏煤田问题. 现代地质, 1997, 11: 305-312

45 张路锁, 张长厚, 张勇, 等. 河北省兴隆煤田区的逆冲构造及其煤田地质勘探与区域构造意义. 地质通报, 2006, 25: 850-857

46 洪作民，白尚金，全秀杰. 辽西地区逆冲断层和推覆体构造. 辽宁地质, 1985, (1): 1-12

47 杨庚, 柴育成, 吴正文. 燕山构造带东段-辽西地区薄皮逆冲推覆构造. 地质学报, 2001, 75: 322-332

48 刘光勋, 江南生. 山西地堑边缘逆掩断裂带的形成机制. 构造地质论丛, 1986, (6): 42-51

49 李树屏, 郑仲科. 我包口推覆构造和逆掩断层剖析. 构造地质论从, 1986, (6): 52-62

50 刘成第, 朱道尊. 我鸟口逆掩断层与推覆体. 构造地质论从, 1986, (6): 63-70

51 孙占亮, 续世朝, 李建荣, 等. 山西五台地区系舟山逆冲推覆构造地质特征. 地质调查与研究, 2004, 27: 28-34

52 秦正永. 燕山地区与变质核杂岩-伸展构造有关的金、银矿找矿远景探讨. 前寒武纪研究进展, 1997, 20: 37-44

53 牛树银, 孙爱群, 李红阳. 冀东慢枝构造外围主拆离滑脱带控矿的研究进展. 地质论评, 2001, 47: 595-596

54 陈先兵, 冀东马兰峪变质核杂岩控矿的初步认识. 有色金属矿产与勘查, 1999, 8: 321-324

55 傅朝义. 河北省变质核杂岩. 地质找矿论从, 1999, 14: 10-16

56 孙冀凡，牛树银，曾垣荣，等. 幔枝构造外围主拆离带型金矿特征一一以尖宝山金矿为例. 内蒙古地质, 2001, (1): 16-23

57 肖成东, 杨伦, 魏晓英, 等. 冀东变质核杂岩中银金矿床地质地球化学特征. 北京大学学报(自然科学版), 2002, 38: 245-251

58 孙爱群, 牛树银, 李红阳. 冀东“长城式”金矿的成因探讨. 地球学报, 2002, 38: 435-442

59 Yan D P, Zhou M F, Song H L, et al. Mesozoic extensional structures of the Fangshan tectonic dome and their subsequent reworking during collisional accretion of the North China Block. J Geol Soc London, 2006, 163: 127-142

60 王涛, 郑亚东, 张进江, 等. 华北克拉通中生代伸展构造研究的几个问题及其在岩石圈减薄研究中的意义. 地质通报, 2007, 26: 1154-1166

61 Coney P J. The regional tectonic setting and possible cause of Cenozoic extension in the North America Cordillera. In: Coward M P, Dewey J F, Hancock P L, eds. Continental Extensional Tectonics. Geol Soc Spec Publ, 1987, 28: 177-186

62 Davis G A, Lister G S. Detachment faulting in continental extension: Perspectives from the southwestern U. S. Cordillera. Geol Soc Am Spec Pap, 1988, 218: 133-159

63 Lister G S, Davis G A. The origin of metamorphic core complex and detachment faults formed during Tertiary continental extension in the northern Colorado River region, U. S. A. J Struct Geol, 1989, 12: 65-94

64 张长厚. 燕山板内造山带中段盖层构造变形及形成机制. 现代地质, 1998, 12(增刊): 118-126

65 李海龙, 张长厚, 邹云, 等. 冀东马兰峪背斜南翼与西部倾伏端盖层构造变形特征及其构造意义. 地质通报, 2008, 27: 1698-1708

66 牛树银, 许传诗, 国连杰, 等. 太行山变质核杂岩构造及成因模式. 河北地质学院学报, 1994, 17: 43-53

67 牛树银, 陈路, 许传诗, 等. 太行山区地壳演化及成矿规律. 北京: 地震出版社, 1994. 1-203

68 牛树银, 孙爱群, 王礼胜. 冀东峪耳崖金矿成矿控矿构造研究. 地球学报, 2000, 21: 236-244

69 雷世和，胡胜军，赵占元，等. 河北阜平、赞皇变质核杂岩构造及成因模式. 河北地质学院学报, 1994, 17: 54-64

70 刘俊来, 关会梅, 纪沫, 等. 华北晚中生代变质核杂岩构造及其对岩石圈减薄机制的约束. 自然科学进展, 2006, 16: 21-26

71 张家声, 徐杰, 万景林, 等. 太行山山前中-新生代伸展拆离构造和年代学. 地质通报, 2002, 21: 207-210

72 张岳桥, 施炜, 廖昌珍, 等. 鄂尔多斯盆地周边断裂运动学分析与晚中生代构造应力体制转换. 地质学报, 2006, 80: 639-647

73 廖昌珍, 张岳桥, 温长顺. 鄂尔多斯盆地东缘边界带构造样式及其区域构造意义. 地质学报, 2007, 81: 466-474

74 Wang Y, Li H M. Initial formation and Mesozoic tectonic exhumation of an intracontinental tectonic belt of the northern part of the Taihang Mountain belt, eastern Asia. J Geol, 2008, 116: 155-172

75 王岳军, 范蔚苔, 郭锋, 等. 赞皇变质穹隆黑云母 ${ }^{40} \mathrm{Ar} /{ }^{39} \mathrm{Ar}$ 年代学研究及其对构造热事件的约束. 岩石学报, 2003, 19: 131-140

76 Stone D S. Basement-involved thrust-generated folds as seismically imaged in the subsurface of the central Rocky Mountain foreland. Geol Soc Am Spec Pap, 1993, 280: 271-318

77 Davis G A, Qian X, Zheng Y, et al. Mesozoic deformation and plutonism in the Yunmeng Shan: A metamorphic core complex north of Beijing, China. In: Yin A, Harrison T M, eds. The Tectonic Evolution of Asia. Cambridge: Cambridge University Press, 1996. 253-280

78 Davis G A, Zheng Y, Wang C, et al. Mesozoic tectonic evolution of the Yanshan segment of the Yinshan fold and thrust belt, northern 
China. In: Hedrix M S, Davis G A, eds. Paleozoic and Mesozoic Tectonic Evolution of Central Asia: From Continental Assembly to Intracontinental Deformation. Geol Soc Am Mem, 2001, 194: 171-197

79 Davis G A, Wang C, Zheng Y D, et al. The enigmatic Yinshan fold-and-thrust belt of northern China: New view views on its intraplate contractional styles. Geology, 1998, 26: 43-46

80 Cope T. Sedimentary evolution of the Yanshan fold-thrust belt, Northeast China. PhD Dissertation. Stanford: Stanford University, 2003. $1-230$

81 刘少峰, 张金芳, 李忠, 等. 燕山承德地区晚侏罗世盆地充填记录及其对盆缘构造作用的指示. 地学前缘, 2004, 11: 245-254

82 胡健民, 刘晓文, 徐刚, 等. 冀北承德地区张营子-六沟走滑断层及其构造意义. 地质论评, 2005, 51: 621-632

83 徐刚, 赵越, 高锐, 等. 燕山褶断带中生代盆地变形-板内变形过程的记录一一下板城、承德-上板城、北台盆地为例. 地球学报, 2006, 27: 1-12

84 张路锁, 张长厚, 张勇, 等. 河北省兴隆煤田区的逆冲构造及其煤田地质勘探与区域构造意义. 地质通报, 2006, 25: 850-857

85 徐杰, 高占武, 宋长青, 等. 太行山山前断裂带的构造特征. 地震地质, 2000, 22: 111-122

86 徐杰, 高占武, 孙建宝, 等. 区域伸展体制下盆-山构造耦合关系的探讨. 地质学报, 2001, 75: 165-174

87 邵济安, 张长厚, 张履桥, 等. 关于华北盆山体系动力学模式的思考. 自然科学进展, 2003, 13: 218-224

88 孟凡雪, 高山, 柳小明. 辽西凌源地区义县组火山岩锆石 U-Pb 年代学和地球化学特征. 地质通报, 2008, 27: 364-373

89 胡健民, 刘晓文, 赵越, 等. 燕山板内造山带早期构造演化一以辽西凌源太阳沟地区为例. 地学前缘, 2004, 11: 255-271

90 胡健民, 赵越, 刘晓文, 等. 辽西凌源地区水泉沟组辉石安山岩铅石 SHRIMP U-Pb 定年及其意义. 地质通报, 2005, 24: 104-109

91 胡健民, 刘晓文, 杨之青. 辽西地区燕山板内造山带早中生代构造变形的年代学限定. 岩石学报, 2007, 23: 605-616

92 Hu J M, Zhao Y, Liu X W, et al. Early Mesozoic deformations of the eastern Yanshan thrust belt, northern China. Int J Earth Sci-Geol Rundsch, 2009, doi: 10.1007/s00531-009-0417-5

93 张宏, 韦忠良, 柳小明, 等. 冀北-辽西地区土城子组的 LA-ICP-MS 测年. 中国科学 D 辑: 地球科学, 2008, 38: 960-970

94 杨进辉, 吴福元, 邵济安, 等. 冀北张-宣地区后城组、张家口组火山岩锆石 U-Pb 年龄和 Hf 同位素. 地球科学, 2006, 31: 71-80

95 牛宝贵, 和政军, 宋彪, 等. 张家口组火山岩 SHRIMP 定年及其重大意义. 地质通报, 2003, 22: 140-141

96 刘健, 赵越, 柳晓明. 冀北承德盆地髺䯽山组火山岩的时代. 岩石学报, 2006, 22: 2617-2630

97 张宏, 王明新, 柳小明. LA-ICP-MS 测年对辽西-冀北地区髺䯽山组火山岩上限年龄的限定. 科学通报, 2008, 53: 1815-1824

98 赵越, 张拴宏, 徐刚, 等. 燕山板内变形带侏罗纪主要构造事件. 地质通报, 2004, 23: 854-863

99 邓晋福, 赵国春, 苏尚国, 等. 燕山造山带燕山期构造叠加及其大地构造背景. 大地构造与成矿学, 2005, 29: 157-165

100 张长厚, 吴涂国, 王根厚, 等. 冀东地区燕山中段北西向构造带: 构造属性及其年代学. 中国科学 D 辑: 地球科学, 2004, 34: 600-612

101 张长厚, 徐德斌, 张维杰, 等. 同构造沉积分析反演逆冲构造变形过程——燕山东段凌源南部中生代逆冲构造变形过程研究. 地学 前缘, 2004, 11: 227-243

102 张新虎, 宋鸿林, 论河北兴隆一带东西向走滑断裂系统. 中国区域地质, 1997, 16: 180-187

103 张长厚, 宋鸿林, 王根厚, 等. 燕山板内造山带中段近东西向中生代右行走滑构造系统. 地球科学, 2001, 26: 464-472

104 Zheng T Y, Chen L, Zhao L, et al. Crustal structure across the Yanshan belt at the northern margin of the North China Craton. Phys Earth Planet Inter, 2007, 161: 36-49

105 王鸿祯. 中国地壳构造发展的主要阶段. 地球科学一中国地质大学学报, 1982, 7: 155-178

106 王鸿祯. 中国岩相古地理图集. 北京: 地质出版社, 1984

107 武法东, 陈钟惠, 张守良, 等. 华北石炭二叠纪的海侵作用. 现代地质, 1995, 9: 284-292

108 李宝芳, 温显端, 李贵东. 华北石炭、二叠系高分辨层序地层分析. 地学前缘, 1999, 6(增刊): 81-94

109 陈世悦, 刘焕杰. 华北地台东部石炭-二叠纪岩相古地理特征. 中国区域地质, 1997, 16: 379-386

110 朱如凯, 许怀先, 邓胜徽, 等. 中国北方地区石炭纪岩相古地理. 古地理学报, 2007, 9: 13-24

111 Mooney W D, Laske G, Masters T G. Crust 5.1: A global crustal model at 5×5 ${ }^{\circ}$ J Geophys Res, 1998, 103: 727-747

112 McQuarrie N, Chase C G. Raising the Colorado Plateau. Geology, 2000, 28: 91-94

113 Platt J P. From orogenic hinterlands to Mediterranean-style back-arc basins: A comparative analysis. J Geol Soc London, 2007, 164: 297-311

114 Kay R W, Kay S M. Delamination and delamination magmatism. Tectonophysics, 1993, 219: 177-189

115 邓晋福, 苏尚国, 刘翠, 等. 关于华北克拉通燕山期岩石圈减薄的机制与过程的讨论: 是拆沉, 还是热侵蚀和化学交代? 地学前缘, 2006, 13: 105-119

116 张拴宏, 赵越, 宋彪, 等. 冀北隆化早前寒武纪高级变质岩区内的晚古生代片麻状闪长岩——锆石 SHRIMP U-Pb 年龄及其构造意义. 
岩石学报, 2004, 20: 621-626

117 张拴宏, 赵越, 刘健, 等. 华北地块北缘晚古生代-中生代花岗岩体侵位深度及其构造意义. 岩石学报, 2007, 23: 625-638

118 Zhang S H, Zhao Y, Song B. Hornblende thermobarometry of the Carboniferous granitoids from the Inner Mongolia Paleo-uplift: Implications for the geotectonic evolution of the northern margin of North China Block. Mineral Petrol, 2006, 87: 123-141

119 Zhang S H, Zhao Y, Song B, et al. Carboniferous granitic plutons from the northern margin of the North China Block: Implications for a late Palaeozoic active continental margin. J Geol Soc London, 2007, 164: 451-463

120 王惠初, 赵风清, 李惠民. 冀北闪长质岩石的锆石 SHRIMP U-Pb 年龄: 晚古生代岩浆弧的地质记录. 岩石学报, 2007, 23: 597-604

121 漆家福, 杨池银. 黄骅盆地南部前第三系基底中的逆冲构造. 地球科学——国地质大学学报, 2003, 28: 54-60

122 漆家福, 于福生，陆克政，等. 渤海湾地区的中生代盆地构造概论. 地学前缘, 2003, 10: 199-206

123 漆家福, 于福生, 陆克政, 等. 渤海湾盆地基岩地质图及其所包含的构造运动信息. 地学前缘, 2004, 11: 299-307

124 葛肖虹. 华北板内造山带的形成史. 地质论评, 1989, 35: 254-261

125 崔盛芹. 论全球中-新生代陆内造山作用与造山带. 地学前缘, 1999, 6: 283-294

126 宋鸿林. 燕山式板内造山带基本特征与动力学探讨. 地学前缘, 1999, 6: 309-316

127 张长厚. 初论板内造山带. 地学前缘, 1999, 6: 295-308

128 罗照华, 邓晋福, 韩秀卿. 太行山造山带岩浆活动及其造山过程反演. 地球科学——中国地质大学学报, 1997, 22: 279-284

129 罗照华, 魏阳, 辛后田, 等. 太行山中生代板内造山作用与华北大陆岩石圈巨大减薄. 地学前缘, 2006, 13: 54-63

130 董树文, 吴锡浩, 吴珍汉, 等. 论东亚大陆的构造翘变——燕山运动的全球意义. 地质论评, 2000, 46: 8-13

131 董树文, 张岳桥, 龙长兴, 等. 中国侏罗纪构造变革与“燕山运动”新诠释. 地质学报, 2007, 81: 1449-1461

132 Dilek Y, Moores E M. A Tibetan model for the early Tertiary western United States. J Geol Soc London, 1999, 156: 929-941

133 Morgan P, Swanberg C A. On the Cenozoic uplift and tectonic stability of the Colorado Plateau. J Geodyn, 1985, 3: 39-63

134 Tapponnier P, Xu Z, Roger F, et al. Oblique stepwise rise and growth of the Tibet Plateau. Science, 2001, 294: 1671-1677

135 Lamb S, Davis P. Cenozoic climate change as a possible cause for the rise of the Andes. Nature, 2003, 425: 792-797

136 Flowers R, Wernicke B P, Farley K A. Unroofing, incision and uplift history of the southwestern Colorado Plateau from (U-Th)/He apatite thermochronometry. Bull Geol Soc Am, 2008, 120: 571-587

137 Roy M, MacCarthy J K, Selverstone J. Upper mantle structure beneath the eastern Colorado Plateau and Rio Grande rift revealed by Bouguer gravity, seismic velocities, and xenolith data. Geochem Geophys Geosyst, 2005, 6, doi: 10.1029/2005GC001008(2005)

138 Roy M, Jordan T H, Pederson J. Colorado Plateau magmatism and uplift by warming of heterogeneous lithosphere. Nature, 2009, 459: 978-982

139 Barnes J B, Ehlers T A. End member models for Andean Plateau uplift. Earth-Sci Rev, 2009, 97: 105-132

140 宋鸿林. 北京房山变质核杂岩的基本特征及成因探讨. 现代地质, 1996, 10: 147-158

141 韦必则, 宋鸿林. 北京房山变质核杂岩构造. 见: 张吉顺, 单文琅, 编. 北京西山地质研究. 武汉: 中国地质大学出版社, 1990. $42-47$

142 Davis G A, Darby B J, Zheng Y, et al. Geometric and temporal evolution of an extensional detachment fault, Hohhot metamorphic core complex, Inner Mongolia, China. Geology, 2002, 30: 1003-1006

143 Darby B J, Davis G A, Zhang X, et al. The newly discovered Waziyu metamorphic core complex, Yiwulushan, western Liaoning Province, North China. Earth Sci Front, 2004, 11: 145-155

144 Liu J L, Davis G A, Lin Z. The Liaonan metamorphic core complex, southeastern Liaoning Province, North China: A likely contributor to Cretaceous rotation of Eastern Liaoning, Korea and contiguous areas. Tectonophysics, 2005, 407: 65-80

145 Yang J H, Wu F Y, Chung S L, et al. Rapid exhumation and cooling of the Liaonan metamorphic core complex: Inferences from ${ }^{40} \mathrm{Ar} /{ }^{39} \mathrm{Ar}$ thermochronology and implications for late Mesozoic extension in the eastern North China Craton. Geol Soc Am Bull, 2007, 119: $1405-1414$

146 Lin W, Wang Q. Late Mesozoic extensional tectonics in the North China Block: A crustal response to subcontinental mantle removal? Bull Soc Géol Fr, 2006, 177: 287-294

147 Lin W, Faure M, Monie P, et al. Polyphase Mesozoic tectonics in the eastern part of the North China Block: Insights from the eastern Liaoning Peninsula massif (NE China). In: Zhai M, Windley B F, Kusky T M, et al, eds. Mesozoic Sub-Continental Lithospheric Thinning Under Eastern Asia. Geol Soc London Spec Publ, 2007, 280: 153-170

148 张家声, Passchier C W, Konopasek J, 等. 云蒙山变质核杂岩抬升过程中伸展拆离和岩浆底辟联合作用的证据. 地学前缘, 2007, 14: 26-39

149 Cope T, Graham S A. Upper crustal response to Mesozoic tectonism in western Liaoning, North China, and implications for lithospheric 
delamination. In: Zhai M, Windley B F, Kusky T M, et al, eds. Mesozoic Sub-Continental Lithospheric Thinning Under Eastern Asia. Geol Soc London, Spec Publ, 2007, 280: 201-222

150 张英利, 渠洪杰, 孟庆任. 燕山构造带滦平早白严世盆地沉积过程和演化. 岩石学报, 2007, 23: 667-678

151 张英利, 孟庆任, 渠洪杰. 燕山构造带风山盆地早白严世的沉积过程. 地质学报, 2008, 82: 769-777

152 张宏，柳小明，袁洪林，等. 辽西凌源地区义县组下部层位的 U-Pb 测年及意义. 地质论评, 2006, 52: 63-71

153 Swisher C C, 汪篠林, 周忠和, 等. 义县组同位素年代新证据及土城子组 ${ }^{40} \mathrm{Ar}-{ }^{39} \mathrm{Ar}$ 年龄测定. 科学通报. 2001, 46: 2009-2012

154 Yang W, Li S G. Geochronology and geochemistry of the Mesozoic volcanic rocks in Western Liaoning: Implications for lithospheric thinning of the North China Craton. Lithos, 2008, 102: 88-117

155 Sengör A M C, Burke K. Relative timing of rifting and volcanism on Earth and its tectonic implications. Geophys Res Lett, 1978, 5: 419-421

156 Cortia G, Boninib M, Conticellic S, et al. Analogue modelling of continental extension: A review focused on the relations between the patterns of deformation and the presence of magma. Earth-Sci Rev, 2003, 63: 169-247

157 Ren J Y, Tamak K, Li S T, et al. Late Mesozoic and Cenozoic rifting and its dynamic setting in eastern China and adjacent areas. Tectonophysics, 2002, 344: 175-205

158 Meng Q R. What drove late Mesozoic extension of the northern China-Mongolia tract? Tectonophysics, 2003, 369: 155-174

159 Dewey J F. Extensional collapse of orogens. Tectonics, 1988, 7: 1123-1139

160 Rey P, Vanderheaghe O, Teyssier C. Gravitational collapse of continental crust: Definition, regimes, and modes. Tectonophysics, 2001, 342: 435-449

161 Flesch L M, Kreemer C. Gravitational potential energy and regional stress and strain rate fields for continental plateaus: Examples from the central Andes and Colorado Plateau. Tectonophysics, 2010, 482: 182-192

162 Vanderhaeghe O, Teyssier C. Partial melting and flow of orogens. Tectonophysics, 2001, 342: 451-472

163 Rey P, Teyssier C, Whitney D L. The role of partial melting and extensional strain rates in the development of metamorphic core complexes. Tectonophysics, 2009, 477: 135-144

164 Sonder L J, England P C, Wernicke B P, et al. A physical model for Cenozoic extension of western North America. In: Coward M P, Dewey J F, Hancock P L, eds. Continental Extensional Tectonics. Geol Soc Spec Publ, 1987, 28: 187-201

165 柳永清, 李佩贤, 田树刚, 等. 冀北滦平晚中生代火山碎屑(熔)岩中钻石 SHRIMP U-Pb 年龄及其地质意义. 岩石矿物学杂志, 2003, 22: $238-244$

166 Zhang H, Liu X M, Zhang Y Q, et al. The zircon U-Pb ages of bottom and top bed of the Zhangjiakou formation in Lingyuan western Liaoning, Luanping northern Hebei as well as its significance. Earth Sci_-J China Univ Geosci, 2005, 16: 115-129

167 张宏, 柳小明, 高山, 等. 辽西凌源地区张家口组的重新厘定及其意义一一来自激光 ICPMS 锆石 U-Pb 年龄的制约. 地质通报, 2005, 24: $110-117$

168 韦忠良, 张宏, 郭文敏, 等. LA-ICP-MS 锆石 U-Pb 测年对辽西-冀北地区晚中生代区域性角度不整合时代的约束. 自然科学进展, 2008, 18: 1119-1127

169 韦忠良, 张宏, 柳小明, 等. 张家口地区张家口组火山岩的 LA-ICP-MS 测年及其地质意义. 自然科学进展, 2008, 18: 523-530

170 高山, 章军锋, 许文良, 等. 拆沉作用与华北克拉通破坏. 科学通报, 2009, 54: 1962-1973 